\title{
SOVEREIGN RISK AND BANK LENDING: EVIDENCE FROM 1999 TURKISH EARTHQUAKE
}

\author{
Yusuf Soner Baskaya \\ Bryan Hardy \\ Șebnem Kalemli-Özcan \\ Vivian Yue \\ Working Paper 22335 \\ http://www.nber.org/papers/w22335 \\ NATIONAL BUREAU OF ECONOMIC RESEARCH \\ 1050 Massachusetts Avenue \\ Cambridge, MA 02138 \\ June 2016, Revised March 2023
}

This paper previously circulated under the title, "Are Government Bonds Bad for Banks? Evidence from a Rare Fiscal Shock". We thank Daron Acemoglu, Mark Aguiar, Koray Alper, Cristina Arellano, Erdem Basci, Javier Bianchi, V.V. Chari, Stijn Claessens, Giancarlo Corsetti, Raquel Fernandez, Jose Louis De-Peydro, Linda Goldberg, Anne Krueger, Alberto Martin, Atif Mian, Pablo Ottonello, Radek Paluszynski, Richard Portes, Ken Rogoff, Larry Wall, and the participants at various conferences for their comments. The views expressed in this paper do not necessarily represent those of the institutions that the authors are affiliated with, nor of the National Bureau of Economic Research.

NBER working papers are circulated for discussion and comment purposes. They have not been peer-reviewed or been subject to the review by the NBER Board of Directors that accompanies official NBER publications.

(C) 2016 by Yusuf Soner Baskaya, Bryan Hardy, Șebnem Kalemli-Özcan, and Vivian Yue. All rights reserved. Short sections of text, not to exceed two paragraphs, may be quoted without explicit permission provided that full credit, including $\odot$ notice, is given to the source. 
Sovereign Risk and Bank Lending: Evidence from 1999 Turkish Earthquake

Yusuf Soner Baskaya, Bryan Hardy, Șebnem Kalemli-Özcan, and Vivian Yue

NBER Working Paper No. 22335

June 2016, Revised March 2023

JEL No. E0,F0,G0,G01,G21

\section{ABSTRACT}

We use an exogenous fiscal shock to identify the transmission of government risk to bank lending due to banks holding government bonds. We illustrate with a theoretical model that for banks with higher exposure to government bonds, a higher sovereign default risk implies lower bank net worth and less lending. Our empirical estimates confirm the model's predictions. The exogenous change in sovereign default risk of Turkish government debt as a result of the 1999 earthquake impacts banks whose balance sheets were exposed more to government bonds. The resulting lower bank net worth translates into lower credit supply. We rule out alternative explanations. Our estimates suggest this channel can explain half of the decline in bank lending following the earthquake. This underlines the importance of the bank balance-sheet channel in transmitting a higher sovereign default risk to reduced real economic activity.

Yusuf Soner Baskaya

University of Glasgow

soner.baskaya@gmail.com

Bryan Hardy

Bank for International Settlements

Centralbahnplatz 2

4051 Basel

Switzerland

bryan.hardy@bis.org

\author{
Șebnem Kalemli-Özcan \\ Department of Economics \\ University of Maryland \\ Tydings Hall 4118D \\ College Park, MD 20742-7211 \\ and CEPR \\ and also NBER \\ kalemli@econ.umd.edu \\ Vivian Yue \\ Economics Department Emory \\ University \\ 602 Fishburne Drive \\ Atlanta, GA 30322 \\ and NBER \\ vivianyue1@gmail.com
}




\section{Introduction}

Financial institutions play a pivotal role in supplying credit both to real sector and sovereign governments. Lending to their own sovereigns increases the exposure of domestic financial institutions to sovereign risk. ${ }^{1}$ An increase in sovereign risk constitutes a direct balance sheet shock to the banks that hold sovereign debt (Gennaioli, Martin, and Rossi (2014), Bocola (2016), Arellano, Bai, and Bocola (2020), Morelli, Ottonello, and Perez (2022)). The decline in asset value reduces bank net worth, which can then constrain bank borrowing and lending. Higher sovereign risk can also affect banks' financial performance by reducing the collateral value of the sovereign bonds and thereby banks' ability to secure funding. These concerns played out most notably in the 2012 Eurozone crisis. However, the surge in government borrowing across both advanced and emerging markets, spurred by the Covid-19 crisis, has brought them back to the fore (Hardy and Zhu (2023)).

Nevertheless, quantifying the effect of sovereign risk on bank balance sheets and credit provision is a challenging task. In particular, it is difficult to identify a causal relationship between sovereign risk and banking sector distress from bank-sovereign doom loop episodes, underlined by the well-known facts of the coincidence of sovereign crises and banking crises (Reinhart and Rogoff (2009)). First, sovereign risk can increase endogenously due to weak banks. In the presence of financial crises, banks under financial stress face insolvency risk, which can result in the need for a government bailout. As governments recapitalize banks to backstop the financial system, functioning as a lender of last resort, the bailouts increase their fiscal burden and so can increase sovereign risk (Acharya, Drechsler, and Schnabl (2014)). Second, bank balance sheet shocks are mostly anticipated and unfold simultaneously with the sovereign debt crisis. For example, banks can actively manage their balance sheets by buying/selling government bonds in response to changes in sovereign risk. Furthermore, the value of the existing government bonds may not change on the bank balance sheet even when sovereign ratings go down, if banks are recording all assets at book value (e.g. held-

\footnotetext{
${ }^{1}$ Sovereign governments mostly borrow from domestic residents (Reinhart and Rogoff (2009), Tomz and Wright (2013), Aguiar and Amador (2014), and Fang, Hardy, and Lewis (2022)).
} 
to-maturity securities in the banking book). In this case, the shock to bank balance sheets may not be observed in the data. A bank will change its behavior in terms of private sector lending given the lower market value of bonds, but the change in the value of the bonds may not be observed on the balance sheet. In this case, one can erroneously attribute the change in bank lending to other factors and/or conclude that there is no effect of increased sovereign risk on lending through bank balance sheets. Third, if distress in the banking sector and/or increased sovereign risk lead to a recession and increased uncertainty, the demand for credit by non-financial private sector will go down. Therefore, in the absence of an exogenous shift in credit supply conditions while keeping demand constant, the variations in the credit provision can simply reflect the recessionary environment potentially affecting loan demand rather than a deterioration in bank balance sheets affecting credit supply. Last but not least, lack of appropriate micro data and therefore reliance on macro data can complicate disentangling factors affecting loan demand from loan supply.

We solve this identification problem by focusing on a unique natural experiment and detailed bank-level data. We first provide an analytical framework to identify the bank balance sheet channel. In particular, based on Morelli et al. (2022), we provide a simple model where banks face different changes in their funding constraint based on their different holdings of government bonds: as the economy experiences an unexpected increase in sovereign risk, the net worth of banks holding government debt is impacted, constraining their lending. We specify the alternative competing channels through which the spillover of an exogenous shock may impact the bank lending (e.g. demand, risky firms, financial repression). The model thus guides the subsequent empirical analysis to disentangle these channels. Second, we utilize the 1999 Marmara Earthquake as an unanticipated exogenous fiscal shock that elevated Turkey's sovereign risk. The unanticipated nature of the shock makes it impossible for banks to accumulate or run down government debt in expectation of sovereign risk. Hence, this helps us to rule out moral hazard and/or risk shifting scenarios due to sovereign default expectations. Third, we use an administrative portfolio data for the universe of banks in Turkey between 1997-2002 to analyse how banks' exposure to sovereign 
debt at the time of the unanticipated exogenous shock affects their net worth and credit provision in the aftermath of the earthquake. ${ }^{2}$

Our empirical strategy relies on the size and the unanticipated nature of the fiscal shock. In terms of the size of the fiscal shock, the Marmara earthquake is significant. It hit on August 17, 1999 at a Richter Scale of 7.6 in the industrial heartland of Turkey. ${ }^{3}$ The region's population share in the country total is 25 percent and GDP share is 50 percent. Total cost of the disaster in August 1999 is estimated to be 20 billion USD, corresponding to 11 percent of GDP in 2000. ${ }^{4}$ In terms of the total damage, the Marmara Earthquake is listed in top ten in the U.S. NGDC Significant Earthquakes database on all earthquakes recorded in history. ${ }^{5}$ To put this event in context, the ratio of damaged buildings (including commercial/industrial premises) is 4 times higher than 1995 Kobe earthquake and 12 times higher than 1994 Northridge earthquake. Following the earthquake, the spreads on government bonds went up as well as the maturity of the government debt got shorter, indicating an increase in default risk. The value of the government bonds declined, constituting a negative shock to banks' balance sheets - more so for the banks with high ex-ante exposure to sovereign debt.

In the empirical analysis, we use a difference-in-differences methodology, comparing banks by their holdings of government debt before and after the earthquake. We first study how the unexpected exogenous earthquake shock lowers the net worth of banks holding government bonds and thus affects their lending. In particular, we show that the earthquake shock impacts bank net worth differently depending on their exposure to government debt. These results indicate that banks' funding constraints tightened by more following the shock when

\footnotetext{
${ }^{2}$ While we focus on the time period around the Earthquake for identification, these concerns and mechanisms continue to be broadly relevant. See for example this news report, where Turkish banks in late 2022 are reportedly concerned about regulation pushing them to hold more government debt.

${ }^{3}$ Throughout the paper, we use the Marmara Earthquakes as two Earthquakes which took place in August 1999 and November 1999. The major one hit cities in the Marmara Region such as Istanbul, Kocaeli, Sakarya, Duzce, Bolu, Yalova, Eskisehir and Bursa in August 17th, 1999 and was associated with substantial economic and social costs. The second one happened on November 12th, 1999 in Duzce Region.

${ }^{4}$ See Akgiray, Barbarosoglu, and Erdik (2004) and National Geophysical Data Center, NOAA. doi:10.7289/V5TD9V7K.

${ }^{5}$ National Geophysical Data Center / World Data Service (NGDC/WDS): Significant Earthquakes 2150 B.C. to A.D. 2022 Database. National Geophysical Data Center, NOAA. doi:10.7289/V5TD9V7K provided in National Oceanic and Athmospheric Administration available at http://www.ngdc.noaa.gov.
} 
they had greater exposure to government debt. Furthermore, we show that this tightening reflects the balance sheet channel, as banks saw valuation effects on their balance sheet and their profits were also negatively affected. Therefore, the empirical analyses validate the model's predictions and point to the bank's balance sheet channel in transmitting the unexpected sovereign risk onto the credit supply.

We find that banks with higher exposures to government debt before the earthquake decreased lending more than the banks with lower exposures. We show that this is not driven by pre-existing trends, changes in credit demand, changes in firm risk (NPLs), deposit outflows, financial repression, ex-ante adjustments in sovereign bond holdings, and other alternative explanations. We use the earthquake as an instrument to show how the impact of this fiscal shock operates through an increase in government bond yields.

Finally, we quantify the impact of the fiscal shock on bank lending, showing that the impact is economically significant. Our estimates imply that a bank that holds 18 percent of its assets in government bonds (the average in our sample) decreases credit to assets ratio by 2 percentage points during regular times (a normal time crowding out effect) and by an additional 1.5 percentage points during the earthquake. These are sizeable effects. The actual decline in credit to assets ratio is 3 percentage points during the earthquake period. Hence, our estimates suggest that the balance sheet channel of the bank-sovereign nexus can explain half of the actual decline in credit provision from August to November 1999, on average.

Our paper contributes in novel ways to the literature on sovereign debt crises and private sector credit access. The existing literature focuses on the rise in sovereign spreads with imminent default and/or actual defaults as the sovereign shock (e.g. Arteta and Hale (2008), Arellano et al. (2020)), whereas we study an episode with no sovereign default but the risk of default rises exogenously via a natural disaster.

More closely, our paper is related to papers focusing on the balance sheet channel through which sovereign risk impacts the private sector (e.g. Gennaioli et al. (2014), Bofondi and Sette (2018), Gennaioli, Martin, and Rossi (2018),Morelli et al. (2022), Gilchrist, Wei, Yue, 
and Zakrajšek (2022), ). However, there is no paper in this literature that can quantify the weakness on bank balance sheets due to the lower valuation of government bonds as a result of an exogenous increase in sovereign risk. ${ }^{6}$

The rest of the paper is structured as follows. Section 2 presents the country background for Turkey. Section 3 presents our data. Section 4 presents the model to motivate the empirical analysis. Section 5 presents the empirical analysis and results. It includes a subsection examining alternative explanations and robustness. Section 6 concludes.

\section{Chronicle of Events}

Towards the end of 1980s, the Turkish economy was characterized by a sizable savings gap arising from both private and public sector, as a result of which Turkey liberalized the capital account in 1989. After the capital account liberalization, the banks started borrowing mainly from international markets and purchased government securities which offered high real returns in domestic currency.

While the capital account liberalization made the government debt finance easier, the political developments in early 1990s resulted in a further deterioration in public finances, resulting in a larger public sector borrowing requirement by 1993-1994. This was followed by a major financial crisis in 1994, after which the government's dependence on the domestic borrowing increased further. In the period between 1994 and 1998, the government incentivized the banks further to finance the public debt by borrowing from abroad in foreign currency and lending to government in domestic currency. This led to higher maturity and foreign exchange risk in the banking sector. ${ }^{7}$ While the government tried to limit the growth

\footnotetext{
${ }^{6}$ See similar work in the European context using firm-bank level data such as Becker and Ivashina (2014), Popov and Van Horen (2015), De Marco (2019), Acharya, Eisert, Eufinger, and Hirsch (2019), Altavilla, Pagano, and Simonelli (2015).

${ }^{7}$ In order to facilitate this process, the monetary policy in the period between 1994 and the end of 1999 was geared towards providing considerable foresight in exchange rate for the banks. As part of the managed floating exchange rate regime implemented by the Central Bank, the monthly depreciation rate of Turkish lira vis-a-vis against hard currencies, more precisely against a basket of 1 US Dollar and 1.5 German Marks, was kept in line with monthly inflation rate. However, the government policies to support the banks' ability
} 
rate of debt stock by cutting net non-interest expenditures, the government debt continued to increase due to high interest expenditures on domestic debt. ${ }^{8}$ However, a series of events, including the Asian Crises and the Russian Crises increased the government's debt burden due to interest rate expenditures on sovereign debt in 1997-1998 period (see Figure 1). In both crises, the government debt stock increased due to higher interest rate burden.

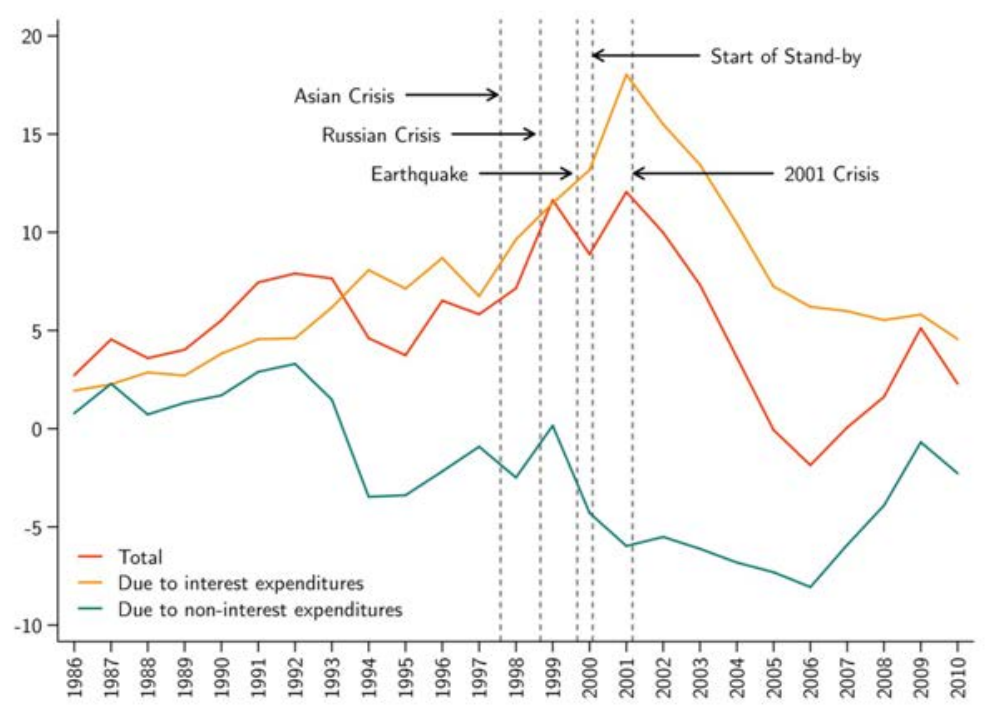

Figure 1: Public Sector Borrowing Requirement/GDP (\%)

However, the tipping point for the sustainability of the Turkish government's debt was the Marmara Earthquake on August 17th 1999. The Marmara Earthquake disturbed the relative stability debt to GDP ratio and led to a rise in the ratio of net debt due to easing in the fiscal stance and increasing contingent fiscal liabilities arising from high economic and social costs of the disaster. For example, the Marmara Earthquake in August 1999 brought

to finance government deficit also included explicit guarantees for deposit liabilities of the banks provided by the Savings Deposit Insurance Fund (SDIF), so that the banks could collect deposits and invest in TL denominated government securities.

${ }^{8}$ See Dervis, Gros, Oztrak, Bayar, and Isik (2004) for a brief account of public sector debt dynamics and its finance in 1990s. 
about an unanticipated total cost estimated to be around 20 billion USD, i.e. roughly 11

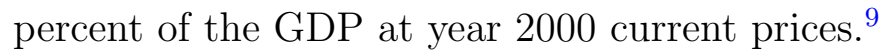

As shown in Table I, the borrowing cost for government and the default risk has increased sharply as a result of the earthquake. Table I shows approximately a 10 percentage point increase in 3 month coupon yields of floating T-bills after the earthquake, Table I also shows the EMBI+ spread increased 100 basis points after the earthquake.

Table I: Sovereign risk

\begin{tabular}{lccc}
\hline & $(1)$ & $(2)$ & $(3)$ \\
\hline & Compounded Interest Rates on \\
Government Bond Auctions (Percent) & $\begin{array}{c}\text { Turkish } \\
\text { Bond-Spreads }\end{array}$ & \\
& $\begin{array}{c}\text { Bills with Approx. } \\
\text { 550 Days to } \\
\text { Maturity }\end{array}$ & $\begin{array}{c}\text { Bills with Approx. } \\
1,050 \text { Days to } \\
\text { Maturity }\end{array}$ & EMBI+ \\
\hline July 1999 & 117.71 & 119.91 & 564 \\
August 1999 & 123.80 & 127.62 & 665 \\
\hline
\end{tabular}

Notes: (1) Source: CBRT for Columns 1 and 2. (2) The numbers in Columns 1 and 2 show the annual compounded interest rates on auctions for 3-month coupons for floating rate government bonds of approximately 550 and 1050 days to maturity. (3) Numbers in Column 3 are the end-of month basis-point value of EMBI+ spread for Turkey.

The risks to public debt sustainability due to the 1998 Russian Crises and the 1999 Earthquake are also visible from the ex-ante real interest rates in government auctions, shown in Figure 2, and the difference between real interest rate and the annual GDP growth rate, shown in Figure 3. The former shows that the ex-ante real interest rates on government debt marked an increase from 20 percent to 36 percent in the aftermath of the August Earthquake. ${ }^{10}$ As a key debt sustainability measure, the difference between real interest

\footnotetext{
${ }^{9}$ These costs consist of government expenditures including those for damaged infrastructure, tax revenue losses due to production losses and tax deferrals and rise in the contingent government liabilities due to the earthquake. See Akgiray et al. (2004) for more.

${ }^{10}$ For calculating the ex-ante real interest rates, we use annualized compounded nominal interest rates on government domestic debt auctions. For calculating inflation expectations, we assume that the inflation expectations are adaptive, in line with the research and policy communications of the CBRT, and calculate
} 
rates and GDP growth further widened in 1999 due to poor growth performance in the first half of 1999 due to the Russian crisis. Both Figure 2, and Figure 3 also highlight the fact that the earthquake happened as a big unanticipated shock just at the peak of concerns about government debt sustainability.

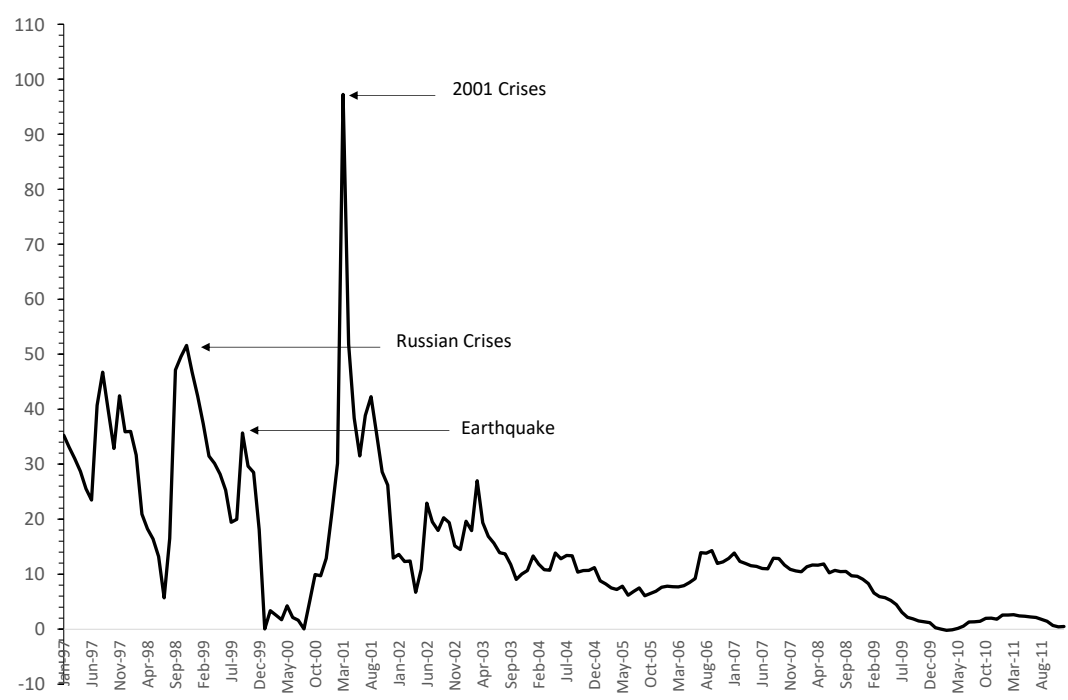

Figure 2: Average Ex-Ante Real Interest Rate on the Primary Auctions on the Government Debt Securities (Percent)

It is important to compare the Earthquake with the Russian Crisis and the 2001 Crisis in terms of how well the latter shocks can serve for the purpose of assessing the causal effect of an exogenous increase in the sovereign risk on bank balance sheets and lending behavior. In comparison, the rise in the government debt stock and the real interest rate during the 2001 crisis were higher. The Russian crisis differs from the 1999 Earthquake, as it is associated with a sizable recession which also suppressed the demand for loans as the Turkish economy

as the weighted average of realized inflation rates and CBRT's target inflation rates. For 1997-2000, we make use of the implicit inflation targets communicated through the CBRT's official monetary policy documents and Governor's speeches. For the period before August 2001, where the expected inflation rates were not published by the CBRT, we generate the expected inflation rates as a 0.5 times the inflation target plus 0.5 times the realized inflation rate. From 2001 onwards, we use explicitly announced inflation targets. 


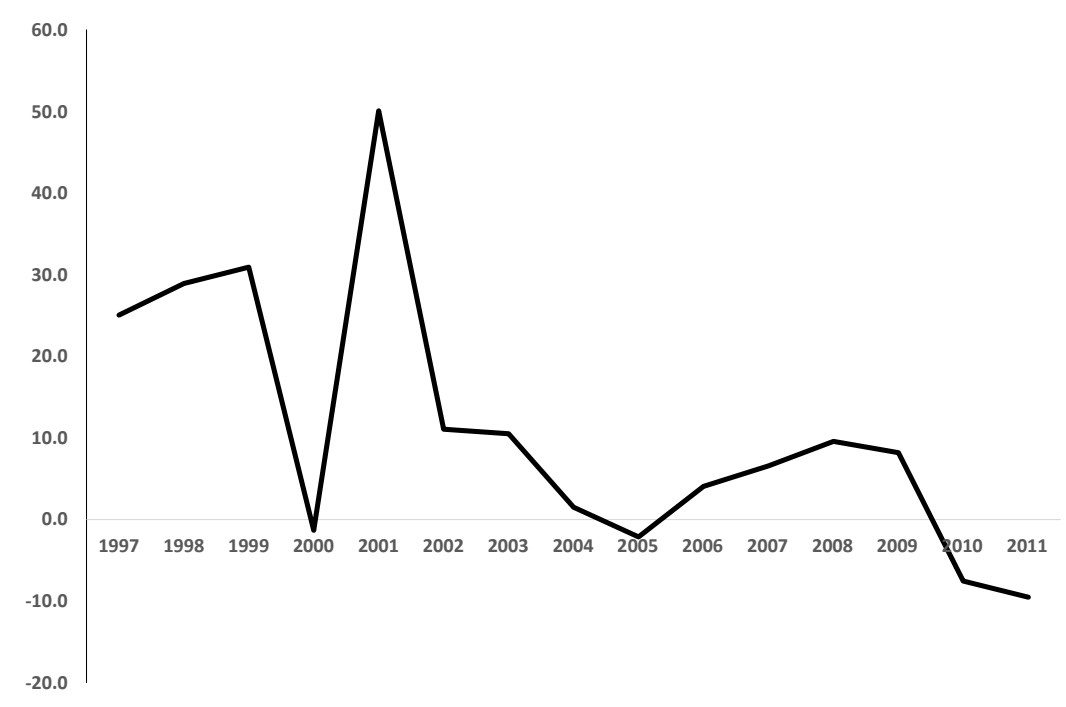

Figure 3: Ex-Ante Average Real Interest Rate on Government Borrowing minus Annual GDP Growth (Percentage Points)

was hit due to its exposure on exports to Russia. On the other hand, during the Earthquake, there was no evidence of decline in loan demand, wide spread defaults as well as a regionwide or country-wide recession. ${ }^{11}$ Finally. unlike the Earthquake, the 2001 Crisis does not provide us a clean experiment for assessing the causal effect of an exogenous increase in the sovereign risk on bank balance sheets and lending behavior, due to the fact that it was quite anticipated starting from late 2000.

Another observation underlying the deterioration in the perceptions of the public debt sustainability was the change in the maturity structure. Figure 4 shows that the share of short term borrowing by government increased from 20 to 50 percent during the earthquake period, which later fell again following the Stand-By Program in December 1999.

It is worth emphasizing that the increase in the debt sustainability concerns following

\footnotetext{
${ }^{11}$ As a support for this argument, while the estimated credit risk of the total banking sector due to the earthquake was 1.5 billion USD in 1999 according to CBRT's estimates (roughly 900 million USD for private bank credits and 600 million USD for public bank credits), the total amount of loan rescheduling as of August 2000 was only 26 million USD.
} 


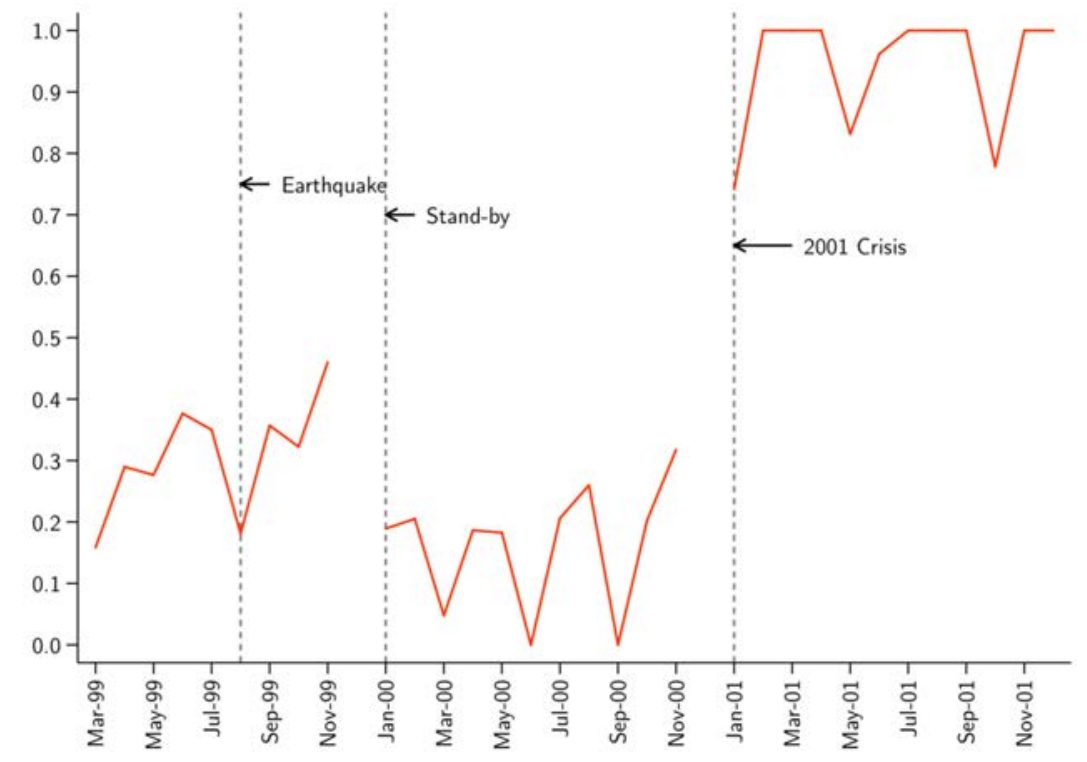

Figure 4: Ratio of Short Term Borrowing in Total Government Borrowing

the Marmara earthquakes was also influential on the timing and content of the Stand-By agreement between Turkey and IMF. The Stand-By program, announced by the Government and the CBRT announced aimed at reducing inflation and restoring the fiscal balance, which involved a 36-month Stand-By agreement with the IMF. ${ }^{12}$ The program led to a temporary improvement in the government borrowing cost, which has mitigated some of the adverse effects on bank balance sheets observed in 1998-1999 period. In addition, the sudden drop in interest rates following the announcement of the exchange rate peg has also revitalized the economic activity and demand for credit. In that sense, the timing and nature of the Stand-By program, as an endogenous policy response to the deterioration in debt sustainability after the earthquake, work as a factor which can bias the negative effects of adverse fiscal shock on bank balance sheets and lending towards zero. Therefore, we think that our key results, i.e. banks with higher government securities holdings being more financially

\footnotetext{
${ }^{12}$ See Özatay and Sak (2002) for an account of the 2000 Stand-By program and 2000-2001 Financial Crises in Turkey.
} 
constraint and cutting the lending more following the earthquake, is more conservative than what unobserved counterfactual of "No Stand-By Response" would have suggested.

Finally the Stand-By program was abandoned in February 2001. While the tipping point of the crisis was a dispute between President and the Prime Minister, the key factors were the deterioration of the overall program due to sluggish structural reform agenda, the weaknesses in the banking sector and the surge in current account deficit real appreciation of the Turkish lira due to high inflation. This was followed up with a new Stand-By Program in 2001 which resulted in a substantial improvement in the economic fundamentals and the end of financial repression due to lower public sector borrowing requirement.

\section{Data and Descriptive Statistics}

This section presents the main dataset in our empirical analysis. We use administrative monthly bank balance sheet data from Turkey for 1997-2011 period. This data is collected regularly as part of the Monitoring Package, which is the data collection and processing system for monitoring and regulation purposes. All the banks operating within Turkey are obliged with reporting their balance sheets as well as extra items by the end of month to the regulatory and supervisory authorities, such as the CBRT and the Banking Regulation and Supervision Agency (BRSA). We also use the extra reporting of the banks, such as the decomposition of the banks' securities portfolio including the information on which particular securities are held by banks by the end of each month, net positions against domestic and foreign creditors and the currency denomination of assets and liabilities through interbank operations. Our sample consists of all banks operating within Turkey, regardless of the ownership status or the classification with respect to the main activity such as deposits banks or investment banks.

Table A1 presents the key descriptive statistics of our banks. We observe a significant cross-sectional heterogeneity with respect to holdings of government securities in banks' balance sheets, where mean is around 18-20 percent depending on the period and it can be 
as high as 46 percent. ${ }^{13}$ Table A2 presents key macro indicators.

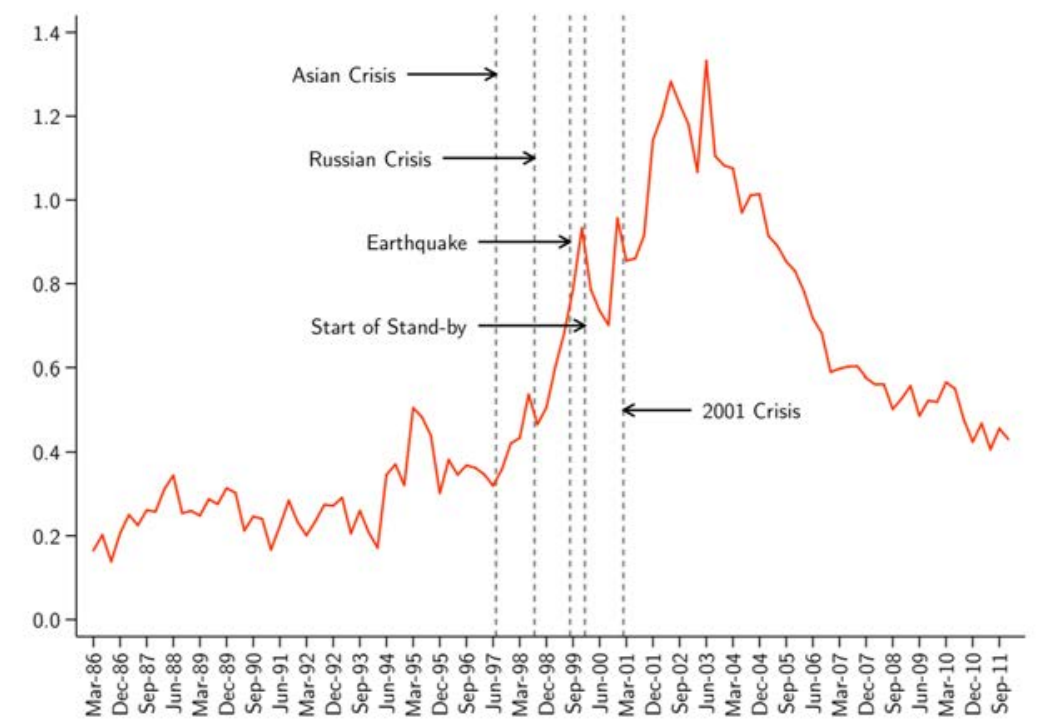

Figure 5: Government Bond Holdings/Credit to Non-Financial Sector

As shown in Figure 5, the banks in Turkey experienced a remarkable portfolio relocation between 1997 and 1999. Banks' government securities holdings as a ratio to the total credit to non-financial private sector doubled within two years. During this period, the bank portfolios displayed some hetereogeneities. Figure 6 plots the share of government securities in bank's total assets for the average bank and for the aggregate, where the aggregate behavior is driven by the large banks. It is clear that there is no significant difference between large banks and small banks until the 2001 crisis, where in the eve of this crisis, both increased their exposure-large banks much more so-to government debt.

Figure 7 presents aggregate data, plotting credit to the non-financial sector as a ratio to total assets of the financial sector, where this ratio falls to $22 \%$ from approximately

\footnotetext{
${ }^{13}$ For a world-wide sample of banks, the average for government debt holdings to assets is 12 percent and for German banks it is 15 percent. See Gennaioli et al. (2018) and Buch, Koetter, and Ohls (2016), respectively.
} 


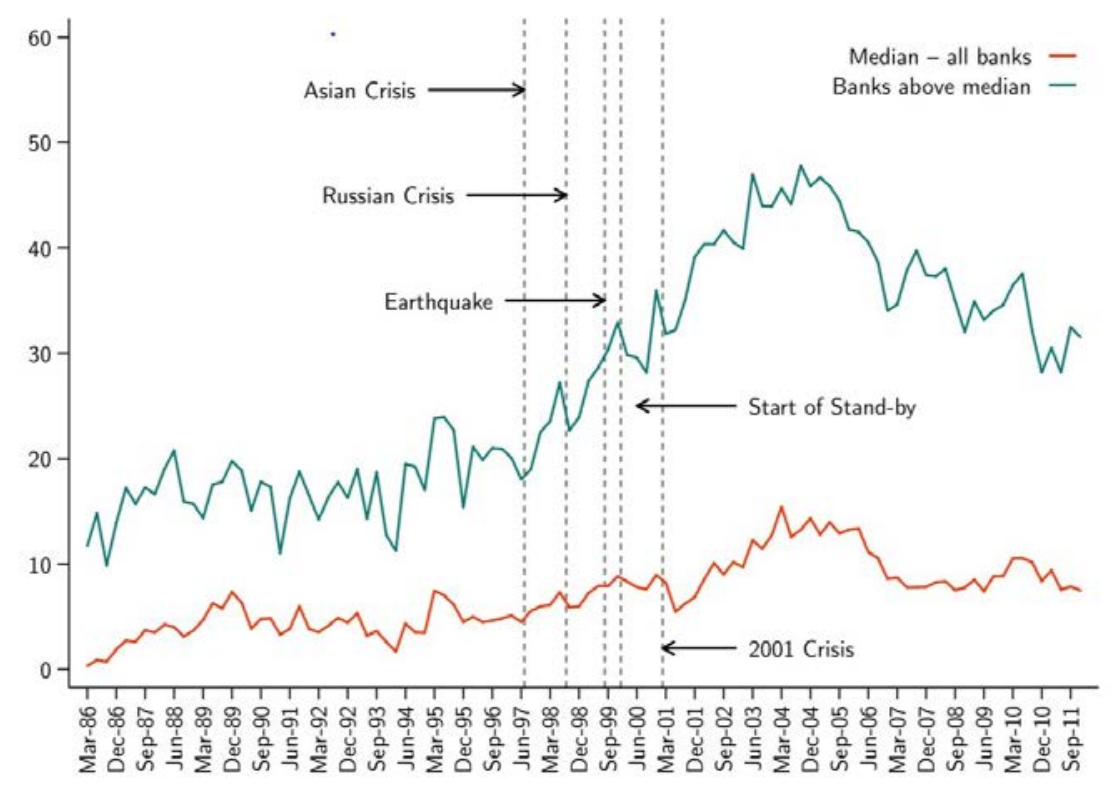

Figure 6: Government Bond Holdings as a Ratio of Banks' Total Assets

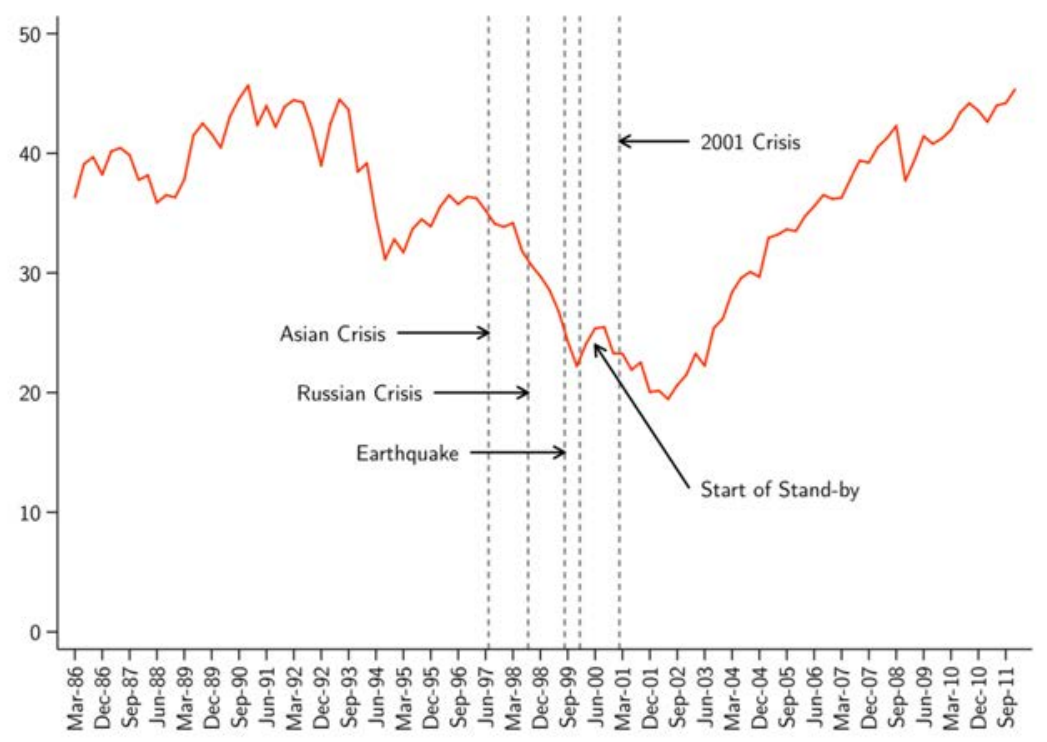

Figure 7: Lending to Private Sector as a Ratio of Banks' Total Assets 
$36 \%$ during the events starting with Asian crisis. This figure mimics our previous Figure 5 where we show typical bank also decreases credit to non-financial sector during this period, increasing loans to government sector by similar amounts.

In the following sections, we first present a theoretical framework to study how an unexpected increase in the sovereign risk negatively impacts the credit supply through banks' balance sheet. Based on the model framework, we then conduct an empirical analysis for Turkey during the earthquake using the bank-level data for Turkey.

\section{Theory}

In this section, we present a theoretical framework to study how sovereign risk negatively impacts the credit supply through banks' balance sheet. We will then use the model to guide the empirical analysis in the next section. ${ }^{14}$ The model is an adapted version of Morelli et al. (2022) to study the sovereign risk and bank's credit supply to firms. We assume that the economy is populated by households, heterogeneous firms, heterogeneous banks, and a government. The households save in bank deposit and own the firms and banks.

Indexed by $j \in[0,1]$, bank $j$ uses the accumulated net worth, $n_{j t}$, and households' deposit, $d_{j t}$, to buy government bonds and claims on firms as well as to pay out dividends to households. Banks can also issue external equity with some cost. Banks' lending to the firms are risky. We assume that the bank $j$ buys claims $a_{K j t}^{i}$ on firm $i \in[0,1]$. The production function is $y_{i t}=z_{i t} k_{i t}^{\alpha}$, and the return from investing in firm $i$ depends on idiosyncratic productivity shocks $z_{i t}$. The bank $j$ 's government bonds holding are denoted by $a_{G j t}$ where the return on the government bonds is $R_{G t}$. We assume that the government has exogenous borrowing and repayment rules to focus on the transmission of sovereign risk through the banking sector. ${ }^{15}$

\footnotetext{
${ }^{14}$ We thank Pablo Ottonello for his guidance on the model.

${ }^{15}$ See Aguiar and Amador (2014) and Wei and Yue (2019) for an extensive literature review about the studies on endogenous sovereign default.
} 
Given these assumptions, The bank's net worth at time $t$ is given by

$$
n_{j t}=\int_{i \in[0,1]} R_{K t}^{i} q_{K t-1}^{i} a_{K j t-1}^{i} d i+R_{G t} q_{G t-1} a_{G j t-1}-R_{d t} d_{t-1}
$$

The flow of funds constraint for bank $j$ is

$$
\int_{i \in[0,1]} q_{K t}^{i} a_{K j t}^{i} d i+q_{G t} a_{G t}=n_{j t}+d_{j t}-d i v_{j t}
$$

We also assume that the banks face a borrowing constraint on the deposits such that

$$
d_{j t} \leq \kappa_{j} n_{j t}
$$

where $\kappa_{j}$ is the borrowing constraint parameter. The borrowing constraint may be due to the agency problem between banks and their creditors as in Gertler and Karadi (2011) and Bocola (2016) or may reflect the capital requirements imposed on banks. For simplicity, we rule out the possibility of bank raising equity. That is, we impose the constraint $d i v_{j t} \geq 0 .{ }^{16}$

The bank survives to the next period with a probability $\psi$. Taking prices as given, bank $j$ chooses $\left\{a_{G j t},\left\{a_{K j t}^{i}\right\}_{i \in[0,1]}, d_{j t}\right\}$ to maximize the present discounted value of dividends paid to the household given by $\mathbb{E}_{t} \sum_{s=0}^{\infty} \beta^{s-t} d i v_{j s}$ subject to (1), (2), and (3).

Based on the model, for a bank that invests all its funds, its total lending to firms is

$$
\int_{i \in[0,1]} q_{K t}^{i} a_{K j t}^{i} d i=n_{j t}(1+\kappa)-q_{G t} a_{G t}
$$

Therefore, when the government is subject to an unexpected shock that raises the sovereign default risk, the realized return on government bonds $R_{G t}$ is lower, reducing banks' net worth $n_{j t}$ based on (1). This result reflects the net worth channel due to the bank's balance sheet. Depending on the composition of their assets and the degree of financial

\footnotetext{
${ }^{16}$ Equivalently, the cost of raising equity is assumed to be prohibitively high. A more general case is analyzed in Morelli et al. (2022). In our data, we do not observe banks issue seasoned equity offering, which reflects the high cost of capital.
} 
constraints $\kappa_{j}$, the net worth of the banks may be affected differently by the exogenous sovereign risk. Therefore, an exogenous sovereign default shock has heterogeneous effect on the banks' ability to supply credit. Banks with higher exposure of government bonds $a_{G t-1}$ face a bigger reduction in its net worth and thus have fewer resources to invest. These banks also experience a bigger increase in their leverage.

\section{Empirical Analysis}

The subsequent empirical analysis studies how banks with different holdings of government bonds transmit an unexpected earthquake shock onto the credit supply in Turkey via the net worth channel. Connecting to our model, we will thus examine in turn (i) how the earthquake shock impacts bank net worth (the balance sheet channel); (ii) identify and quantify the causal impact of an increase in sovereign risk on bank lending; (iii) the effect of increasing government bond yields on lending given sovereign exposure; and (iv) alternative explanations for these relationships. Regarding the latter, our approach will help separate this channel out from other possible channels: the riskier borrower channel $\left(R_{k t}^{i}\right.$ declines, decreasing net worth); the repression channel (banks increase $a_{G t}$, and so must decrease $a_{K t}$ ); the deposits channel $\left(d_{j t}\right.$ decreases, so dividends or the left-hand side of Equation (2) must decline) $;^{17}$ and the demand channel ( $a_{K t}$ is directly affected by the shock).

Our regression framework follows a difference-in-difference strategy and takes the following basic form:

$$
\begin{aligned}
& y_{i t}=\alpha_{i}+\alpha_{t}+\beta_{0} \text { GovBondHoldings }_{i t-1} \\
& \quad+\beta_{1} \text { GovBondHoldings }_{i t-1} \times \text { Earthquake }_{t}+X_{i t-1} \Gamma+\epsilon
\end{aligned}
$$

\footnotetext{
${ }^{17}$ The model features only one funding source for simplicity, but banks in reality can also tap non-deposit funding.
} 
where $y_{i t}$ is our outcome of interest, GovBondHoldings $s_{i t-1}$ is the lagged value of each bank's government bond holdings normalized by assets and Earthquake en $_{t}$ is a dummy variable equal to 1 over August 1999-November 1999. $X_{i t-1}$ is a vector of controls for bank characteristics (such as cash holdings, capital, size), as well as their interaction with the earthquake dummy; or the interaction of GovBondHoldings with other crisis dummies. The Asian crisis dummy is equal to 1 over July 1997-December 1997. The Russian crisis dummy is equal to 1 over August 1998-January 1999. The 2001 Turkish crisis dummy is equal to 1 over February 2001-December 2001. $\alpha_{i}$ and $\alpha_{t}$ are bank and time fixed effects, which control for the time-invariant unobserved heterogeneity across banks and all common shocks to the banks (including aggregate demand effects due to the earthquake), respectively. In some specifications, we saturate the model further with bank-quarter fixed effects, to control for slower moving factors that are specific to each bank. In our regressions, $\beta_{1}$ is of primary interest, as it would reflect differential outcomes following the earthquake for banks with different levels of exposure to government bonds.

\section{$A$ Inspecting the Model Mechanism: the Balance Sheet Channel}

We first examine if the earthquake shock actually generated a shock to bank balance sheets, specifically to their net worth. We check first how the valuation of financial assets on bank balance sheet changed, and then how bank net worth changed, given greater exposure to the government at the time of the earthquake.

Table II examines banks' financial asset valuation changes between current and previous period as a ratio to their total assets. In the main period of our study, banks could hold sovereign debt either in their trading book, where securities are marked-to-market, or in their banking book, where securities are held at face value (e.g. hold-to-maturity). For these latter holdings, banks in Turkey had to account for valuation effects in a separate item on their financial statements. Regardless of where the security was held, a change in the value 
of government securities would affect the profit and thus net worth of the bank. ${ }^{18}$ To provide some evidence that the earthquake generated a valuation shock to banks holding government debt, we examine the valuation change in their securities portfolio held in the banking book. Then for a more complete view (which captures also the valuation effects for securities held in the trading book), we examine the impact of the earthquake on the bank's net worth.

We find that the banks with higher share of government securities in their balance sheets had a higher decline in the value of their banking book securities portfolio, given the decline in the value of this asset with the fiscal shock. Note that there was not a generalized valuation decline among banks during the earthquake (column 1), but the negative valuation effects were specific to those holding government bonds.

This valuation decline is reflected in a decline in bank net worth. Figure 8 illustrates this by comparing banks with above and below median holdings of government bonds. Banks were similar along these measures until the earthquake shock, which provides some validation of pre-trends for our difference-in-differences approach. Table III corroborates the impact in our regression framework. Banks holding more government debt saw larger declines in their net worth following the earthquake. This holds even after controlling for other bank characteristics interacted with the earthquake, which could capture other channels by which the earthquake could impact bank net worth (column 4). Thus the decline in value of banks' government bond holdings drives a decline in net worth. While regressions in Tables II and III have been specified in changes, Table B4 in the appendix shows that the relationships also hold in levels. In particular, the decline in net worth is robust to including bank-quarter fixed effects (column 6). This table, along with Figure B2, also document that the balance sheet shock impacts profits.

\footnotetext{
${ }^{18}$ For a bank which hold the same government security on their banking book both at time $\mathrm{t}-1$ and $\mathrm{t}$, an increase (a decrease) in the price of that security induces a revaluation which increases (decreases) its monetary value. Therefore, a decline in the price of bonds (e.g. due to the earthquake) results in the decline in the equity via negative effect on the valuation account. Holding that security in their trading book, the bank directly records the market value of the asset, which change also affects net worth. After December 2002 , banks were required to hold all sovereign bonds in the trading book, and so mark them to the market value in their financial statements.
} 
Table II: Earthquake and Valuation Effects

(1) (2)

(3)

\begin{tabular}{|c|c|c|c|}
\hline Gov Bond Holdings ${ }_{i t-1} \times$ Earthquake $_{t}$ & $\begin{array}{c}-0.00653^{* *} \\
(0.00264)\end{array}$ & $\begin{array}{r}-0.0110^{* * *} \\
(0.00166)\end{array}$ & $\begin{array}{r}-0.0101^{* * *} \\
(0.00295)\end{array}$ \\
\hline Gov Bond Holdings $s_{i t-1}$ & 0.0104 & 0.0151 & 0.0130 \\
\hline Earthquake $_{t}$ & $\begin{array}{c}(0.0108) \\
-0.00587 \\
(0.00585)\end{array}$ & (0.0108) & $(0.0165)$ \\
\hline Russia $_{t}$ & $-0.0261^{*}$ & & \\
\hline Asia $_{t}$ & -0.00281 & & \\
\hline 2001 Crisis $_{t}$ & $\begin{array}{l}-0.0220^{*} \\
(0.0118)\end{array}$ & & \\
\hline Observations & 4954 & 4954 & 4954 \\
\hline$R^{2}$ & 0.004 & 0.0002 & 0.000 \\
\hline Banks & 82 & 82 & 82 \\
\hline BankFE & No & No & Yes \\
\hline TimeFE & No & Yes & Yes \\
\hline \multicolumn{4}{|c|}{$\begin{array}{l}\text { Dependent variable is change in financial asset valuation adjustments, winsorized at } 1 \% \text {. } \\
\text { Earthquake is a dummy equal to } 1 \text { for Aug } 1999-\text { Nov } 1999 \text {. Asia is a dummy equal to } \\
1 \text { for Jul 1997- Oct } 1997 \text {. Russia is a dummy equal to } 1 \text { for Sep } 1998-\text { Nov } 1998.2001 \\
\text { Crisis is a dummy equal to } 1 \text { for Dec } 2000-\text { Dec } 2001 \text {. Sample spans } 1997-2002 . R^{2} \text { is } \\
\text { within } R^{2} \text {. Errors are clustered at the bank and month levels. }{ }^{*} \mathrm{p}<0.10,{ }^{* *} \mathrm{p}<0.05 \text {, } \\
* * * \mathrm{p}<0.01\end{array}$} \\
\hline
\end{tabular}


Table III: Earthquake and Net Worth

\section{(1)}

(2)

(3)

\begin{tabular}{|c|c|c|c|}
\hline Gov Bond Holdings S $_{i-1} \times$ Earthquake $_{t}$ & $-0.0287^{* *}$ & $-0.0338^{* *}$ & \\
\hline Gov Bond Holdings ${ }_{i t-1}$ & 0.0104 & 0.0159 & 0.00862 \\
\hline Gov Bond Holdings ${ }_{i t-1} \times$ Russia $_{t}$ & $(0.0154)$ & $(0.0155)$ & $\begin{array}{c}(0.00976) \\
-0.0308 \\
(0.0208)\end{array}$ \\
\hline Gov Bond Holdings $s_{i t-1} \times$ Asia $_{t}$ & & & $\begin{array}{l}-0.0412^{* *} \\
(0.0175)\end{array}$ \\
\hline Gov Bond Holdings $\mathrm{s}_{i t-1} \times 2001$ Crisis $_{t}$ & & & $\begin{array}{c}0.0246 \\
(0.0333)\end{array}$ \\
\hline Observations & 5057 & 5057 & 5057 \\
\hline$R^{2}$ & 0.071 & 0.077 & 0.078 \\
\hline Banks & 82 & 82 & 82 \\
\hline BankFE & Yes & Yes & Yes \\
\hline TimeFE & Yes & Yes & Yes \\
\hline Cont & Yes & Yes & Yes \\
\hline ControlsXEarthquake & No & Yes & Yes \\
\hline \multicolumn{4}{|c|}{$\begin{array}{l}\text { Dependent variable is the change in net worth to assets, winsorized at } 1 \% \text {. Controls include } \\
\text { change in interbank balances, cash holdings, private lending (each normalized by assets) and } \\
\text { log assets. Cash is winsorized at } 1 \% \text {. Earthquake is a dummy equal to } 1 \text { for Aug } 1999-\text { Nov } \\
1999 \text {. Asia is a dummy equal to } 1 \text { for Jul } 1997-\text { Oct } 1997 \text {. Russia is a dummy equal to } 1 \text { for } \\
\text { Sep } 1998 \text { - Nov 1998. } 2001 \text { Crisis is a dummy equal to } 1 \text { for Dec } 2000-\text { Dec } 2001 \text {. Sample } \\
\text { spans } 1997-2002 . R^{2} \text { is within } R^{2} \text {. Errors are clustered at the bank and month levels. a p } \\
<0.11 * \mathrm{p}<0.10,{ }^{* *} \mathrm{p}<0.05,{ }^{* *} \mathrm{p}<0.01\end{array}$} \\
\hline
\end{tabular}




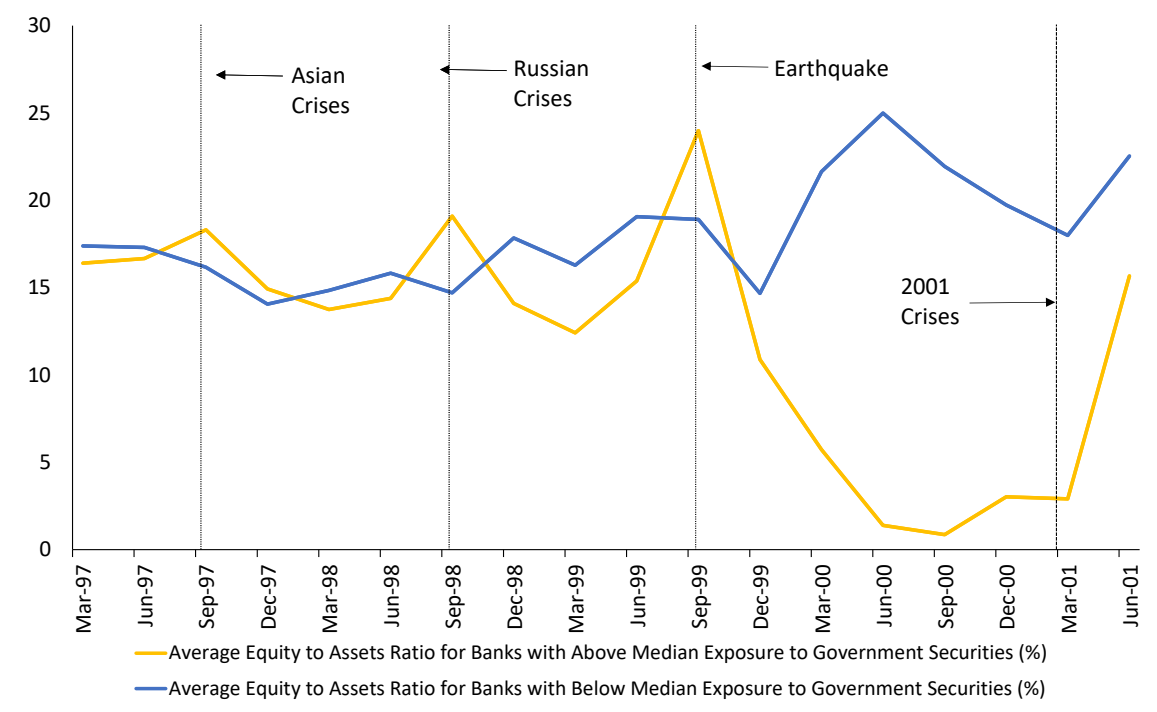

Figure 8: Net Worth of Banks with High-Low Exposure to Government Bond Market

In terms of magnitudes from the estimates (column 6 of Table B4), we find that a bank in 90th percentile of the government bond exposure distribution, which holds roughly $40 \%$ of its portfolio in government securities, suffers a 1.9 percentage point decline in its' net worth as a share to its assets. The average bank net worth in the sample is $17 \%$ of assets, so this represents over a $10 \%$ decline in net worth. ${ }^{19}$ For a bank with average government bond holdings (18\%), the decline is 0.8 percentage points of assets, or a still sizeable $5 \%$ decline of the average net worth.

\footnotetext{
${ }^{19}$ Note that net worth and government bond holdings are negatively correlated, so it is not necessarily the case that banks with the highest holdings also have the highest net worth.
} 


\section{$B$ Government Exposure during the Earthquake and Private Lend- ing}

We next move to examining directly the impact of exposure to government bonds during the earthquake on private lending, our primary outcome of interest. We discuss in more detail how our regression approach helps identify the causal impact of sovereign risk on bank lending.

Government bond holdings are not random. We first try to understand their determinants and correlated factors with holdings across banks. Also important for our identification is whether these determinants of government bond holdings vary systematically at the time of earthquake. This helps us identify which variables may capture similar variation across banks as does their government bond holdings, and if they may shift during the earthquake. It is important to control for these variables in order to rule out other channels that may be affected by the earthquake shock and thus spuriously drive our results with government bond holdings.

Table IV examines the variables correlated with the government bond holdings. The main correlates of government bond holdings are interbank balances, cash holdings, and capital. Banks with a higher capital ratio hold less government bonds in their portfolio, but increase their holdings during the earthquake, as these are the stronger banks. Bank with larger interbank balances also hold fewer government bonds, especially so during the earthquake, since greater surpluses on their interbank balances means they need less government bond holdings as collateral. Banks with higher cash holdings than average hold less government debt, but increase their holdings at the time of earthquake. This can be associated with risk taking behavior but also with supplying government with the needed funds since these are the more liquid banks.

In addition to controlling for these factors in our regressions, we make some other observations that justify this empirical approach. First, for our difference-in-difference approach to be valid, we need to ensure that there are no parallel trends in our outcome variables (e.g. 
lending) based on the treatment variable (government bond holdings). As can be seen in Figures 8 and B2, banks with greater exposure to sovereign bonds did not appear to perform worse before the earthquake than other banks in terms of profits and net worth. Figure 9 shows this is also the case for the loan provision. Thus, a negative and significant coefficient on the interaction between the government debt exposure and the earthquake variable does not reflect the already existing deterioration for banks with higher exposure, but rather the impact of the earthquake on the banks' balance sheet performance and the loan provision. We further address this concern with a placebo test in the appendix.

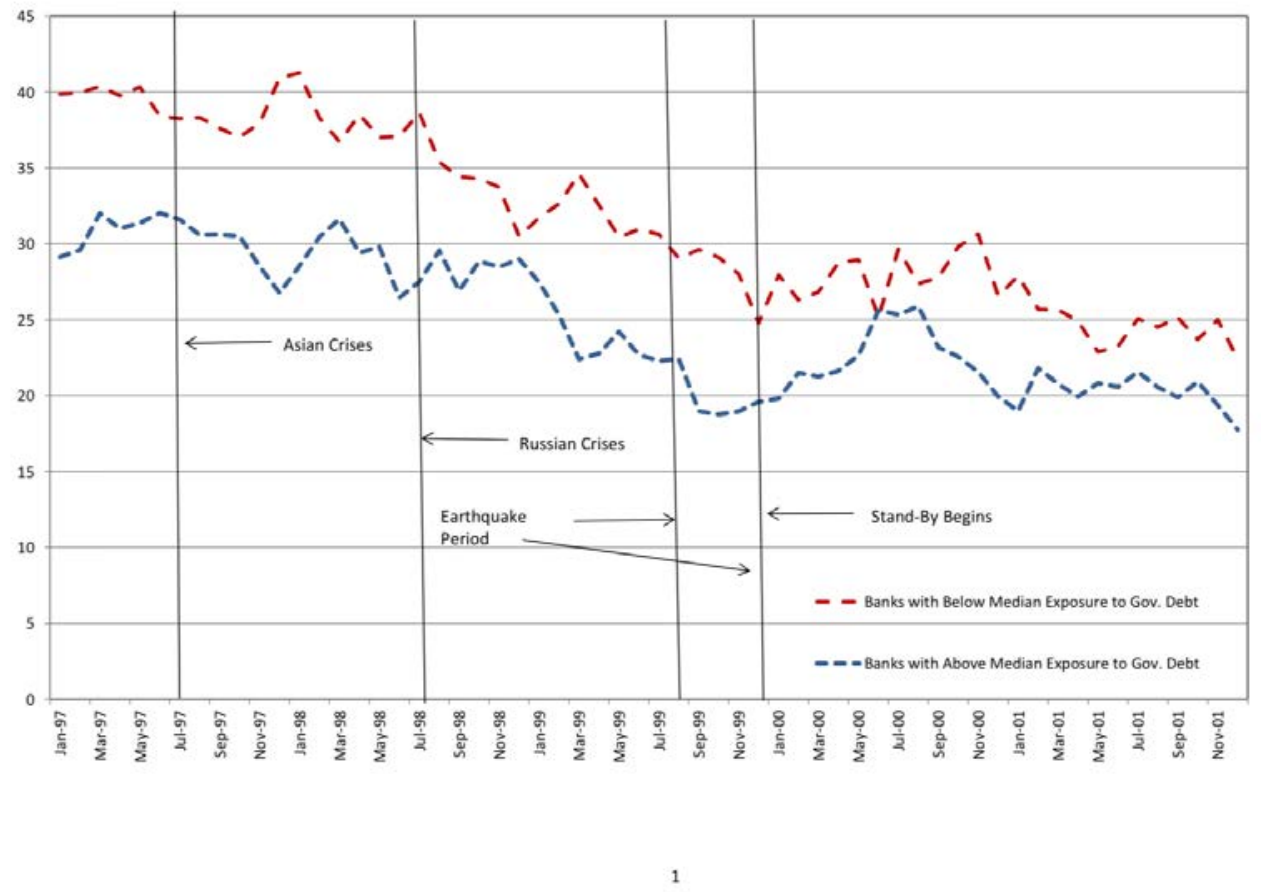

Figure 9: Loan Provision of Banks with High-Low Exposure to Government Bond Market

Another important observation for our identification is the fact that there was no visible change in government bond holdings in the aftermath of the earthquake. Table A3 presents 
the average ratios for government securities to assets and loans to assets before and after the earthquake. It is clear that average exposure to public debt stayed around the same but average credit provision declined. This highlights that the shock was not anticipated and banks were not otherwise adjusting their portfolio in a way that would affect our estimation.

Now, we go into more depth to causally identify the effect of an increase in government debt holdings on bank credit provision. We utilize the unique natural experiment of the earthquake to isolate one direction of the bank-sovereign nexus, as it generates an unanticipated fiscal burden (and thus increases sovereign risk), but does not directly impact the banking sector. We use the same regression setup as in Equation 8. The outcome of interest is banks' lending $L_{i t}$. We measure the loan supply with the credit provision normalized by assets, that is, the share of credit to non-financial firms in total assets.

In our controls, we include the main potential determinants of government bond holdings (interbank assets, cash, log assets, and capital) that may be correlated with loan provision at regular times and at crisis times, as explored above. We also include their interactions with the earthquake to control for other channels correlated with bond holdings by which the earthquake may have impacted bank lending.

In order to assure that we do not capture the effects of other events that might have affected the sustainability of the government debt differently, we also control for the interactions of government debt with the other major events that happened before and after the 1999 Marmara Earthquake, such as Asia Crises, Russia Crisis, Stand-by agreement, and 2001 crisis. The direct effects of these events are absorbed by the month fixed effects. We use lag government debt holdings by 1 month, but in the appendix examine robustness to lagging by 2 or 3 months, using a time invariant measure, and adjusting the earthquake window, among other checks.

First, to highlight the intuition, Table V estimates a simple cross sectional regression by collapsing the sample in two periods as pre- and post-earthquake. Loans to the private sector as a ratio to total assets for each bank are averaged over the period from August 1999 to November 1999. Similarly government bond holdings as a ratio to total assets for 
Table IV: Correlates of government bond holdings

\begin{tabular}{|c|c|c|c|c|}
\hline & (1) & $(2)$ & $(3)$ & $(4)$ \\
\hline Interbank Balances $_{i t}$ & $-0.445^{* * *}$ & $-0.402^{* * *}$ & $-0.440^{* * *}$ & $-0.396^{* * *}$ \\
\hline Cash Holdings $_{i t}$ & $\begin{array}{l}(0.0340) \\
-0.847 \\
(0.824)\end{array}$ & $\begin{array}{l}-2.104^{* *} \\
(1.028)\end{array}$ & $\begin{array}{l}-0.953 \\
(0.820)\end{array}$ & $-2.202^{* *}$ \\
\hline $\mathrm{NPLs}_{i t}$ & $\begin{array}{l}-0.537 \\
(0.551)\end{array}$ & $\begin{array}{l}-0.218 \\
(0.602)\end{array}$ & $\begin{array}{l}-0.490 \\
(0.552)\end{array}$ & $\begin{array}{l}-0.162 \\
(0.605)\end{array}$ \\
\hline Capital $_{i t}$ & $\begin{array}{c}-0.0577^{* * *} \\
(0.0197)\end{array}$ & $\begin{array}{c}-0.0645^{* * *} \\
(0.0174)\end{array}$ & $\begin{array}{c}-0.0610^{* * *} \\
(0.0219)\end{array}$ & $\begin{array}{c}-0.0657^{* * *} \\
(0.0178)\end{array}$ \\
\hline $\operatorname{Size}_{i t}$ & $\begin{array}{c}0.00860 \\
(0.00546)\end{array}$ & $\begin{array}{c}0.0106 \\
(0.0126)\end{array}$ & $\begin{array}{l}0.00957^{*} \\
(0.00545)\end{array}$ & $(0.0121$ \\
\hline Domestic Bank $_{i}$ & $\begin{array}{l}-0.00215 \\
(0.0253)\end{array}$ & & -0.00451 & \\
\hline State Bank $_{i}$ & $\begin{array}{c}0.0107 \\
(0.0272)\end{array}$ & & $\begin{array}{c}0.0164 \\
(0.0284)\end{array}$ & \\
\hline Interbank Balances $_{i t} \times$ Earthquake $_{t}$ & & & $\begin{array}{l}-178.4^{*} \\
(100.8)\end{array}$ & $\begin{array}{l}-202.4^{* * *} \\
(67.17)\end{array}$ \\
\hline Cash Holdings $_{i t} \times$ Earthquake $_{t}$ & & & $\begin{array}{c}3.009^{* * *} \\
(0.646)\end{array}$ & $\begin{array}{c}2.987^{* * *} \\
(0.649)\end{array}$ \\
\hline $\mathrm{NPLs}_{i t} \times$ Earthquake $_{t}$ & & & $\begin{array}{l}0.0893 \\
(0.577)\end{array}$ & $\begin{array}{r}0.0594 \\
(0.485)\end{array}$ \\
\hline Capital $_{i t} \times$ Earthquake $_{t}$ & & & $\begin{array}{l}0.163^{* *} \\
(0.0796)\end{array}$ & $\begin{array}{c}0.165^{* *} \\
(0.0810)\end{array}$ \\
\hline Size $_{i t} \times$ Earthquake $_{t}$ & & & $\begin{array}{l}-0.00622 \\
(0.00442)\end{array}$ & $\begin{array}{l}-0.00766 \\
(0.00493)\end{array}$ \\
\hline 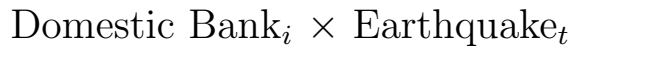 & & & $\begin{array}{l}0.0108 \\
(0.0236)\end{array}$ & $\begin{array}{c}0.0166 \\
(0.0289)\end{array}$ \\
\hline 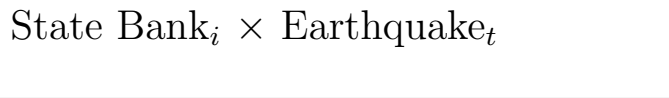 & & & $\begin{array}{l}-0.106^{* *} \\
(0.0401)\end{array}$ & $\begin{array}{c}-0.0964^{* *} \\
(0.0384)\end{array}$ \\
\hline Observations & 5145 & 5145 & 5145 & 5145 \\
\hline$R^{2}$ & 0.0503 & 0.0383 & 0.0586 & 0.0516 \\
\hline Banks & 82 & 82 & 82 & 82 \\
\hline BankFE & No & Yes & No & Yes \\
\hline TimeFE & Yes & Yes & Yes & Yes \\
\hline
\end{tabular}


each bank are also averaged over the period from January 1999 to July 1999, along with the controls in $X$. This simple cross-sectional regression shows that the banks with higher pre-earthquake exposure to government bonds had lower lending than other banks after the earthquake. This effect is robust to including controls correlated with bond holdings and to excluding state owned banks in Column 3 and banks that were ever taken over by Savings Deposit Insurance Fund (SDIF) in Column 4.

Table V: Pre-Earthquake Exposure and Post-Earthquake Lending

\begin{tabular}{|c|c|c|c|c|}
\hline & $\begin{array}{l}\text { (1) } \\
\text { All }\end{array}$ & $\begin{array}{l}(2) \\
\text { All }\end{array}$ & No $\stackrel{(3)}{\text { State }}$ & No TMSF \\
\hline Avg Gov Bond Holdings before EQ & $\begin{array}{c}-0.305^{* *} \\
(0.127)\end{array}$ & $\begin{array}{c}-0.384^{* * *} \\
(0.123)\end{array}$ & $\begin{array}{c}-0.413^{* * *} \\
(0.126)\end{array}$ & $\begin{array}{c}-0.322^{*} \\
(0.164)\end{array}$ \\
\hline $\begin{array}{l}\text { Observations } \\
\text { r2 } \\
\text { Controls }\end{array}$ & $\begin{array}{c}78 \\
0.0612 \\
\text { No }\end{array}$ & $\begin{array}{c}78 \\
0.282 \\
\text { Yes }\end{array}$ & $\begin{array}{c}73 \\
0.315 \\
\text { Yes }\end{array}$ & $\begin{array}{c}58 \\
0.300 \\
\text { Yes }\end{array}$ \\
\hline $\begin{array}{l}\text { Dependent variable is the average private } \\
\text { are the pre-earthquake (Jan } 1999-\text { Jul } 199 \\
\text { capital, log assets, and interbank assets. A } \\
\text { Sample spans } 1997-2002 . \text { Robust standard } \\
0.05, * * * \text { p }<0.01\end{array}$ & $\begin{array}{l}\text { variables } \\
\text { rrors are }\end{array}$ & $\begin{array}{l}\text { peept log a } \\
\text { ported in }\end{array}$ & $\begin{array}{l}\text { c 1999. Ind } \\
\text { bond holdi } \\
\text { ets) are in r } \\
\text { ranthesis. }\end{array}$ & $\begin{array}{l}\text { ndent variable } \\
\text { cash holdings } \\
\text { to total assets } \\
<0.10,{ }^{* *} \text { p }\end{array}$ \\
\hline
\end{tabular}

Table VI presents the results of the full panel regression. Column 1 shows the basic relationship, column 2 adds interactions of bond holdings with the other major events, column 3 adds interactions of the controls with the earthquake dummy, and column 4 drops banks that were ever state-owned. Columns 5 and 6 add a control for contemporaneous holdings of government debt, consistent with our conceptual framework.

These results show that banks with larger exposure to government bonds had lower lending following the earthquake. The range of estimate suggest that the decline in lending is $1-1.5 \%$ of assets for the median exposure bank (holding $16 \%$ of assets as government bonds) and 2.5-3.5\% of assets for the 90th percentile bank (with $40 \%$ exposure). The overall decline in lending was 2.9 percentage points, so the average holdings (18\%) explains roughly half of the decline $\left(0.08^{*} 18=1.44\right)$. Note that the direct effect of holding government bonds is consistently negative. The bank with average holdings has 3.5 percentage point of asset lower private lending relative to a bank without exposure. This captures the natural crowding out 
effect, as putting more resources towards government lending means less available for private lending. The balance sheet shock tightens the bank's constraints, leading them to contract lending, more so for banks that had already crowded out private lending by picking up more government bonds.

The effect of bond holdings during other events is intuitive. We do not find significant differential impact across banks by their holdings of government debt following the Asian and Russian crises. These events are external shocks. Although they had an effect on Turkish economy, and even on the spreads to a certain extent via contagion fears, they should not have a differential effect on the balance sheet of banks holding high or low levels of Turkish bonds since these events do not constitute a direct fiscal shock to Turkish government's ability to pay its debt.

By the same token, we should expect to see a large negative effect for Turkey's own banking, currency, and sovereign debt crisis of 2001. These columns show a similar negative effect of government bond holdings during the 2001 crisis, though not significant. While the 2001 crisis was larger, it was an endogenous crisis that was also anticipated in advance, contributing to the lower and less precisely measured effect than expected. ${ }^{20}$ Although both the Earthquake period and the 2001 Crisis period are associated with heightened sovereign risk and decline in the value of government bonds, the earthquake allows us to directly estimate the causal impact given the exogenous and unanticipated nature of this event.

\footnotetext{
${ }^{20}$ These patterns can be seen throughout our other tables in the text and appendix. The coefficient on the interaction with the 2001 crisis is negative and sometimes significant, though not always, with magnitudes similar to that of the earthquake. The coefficients on the Russian and Asian crises are only sporadically significant.
} 


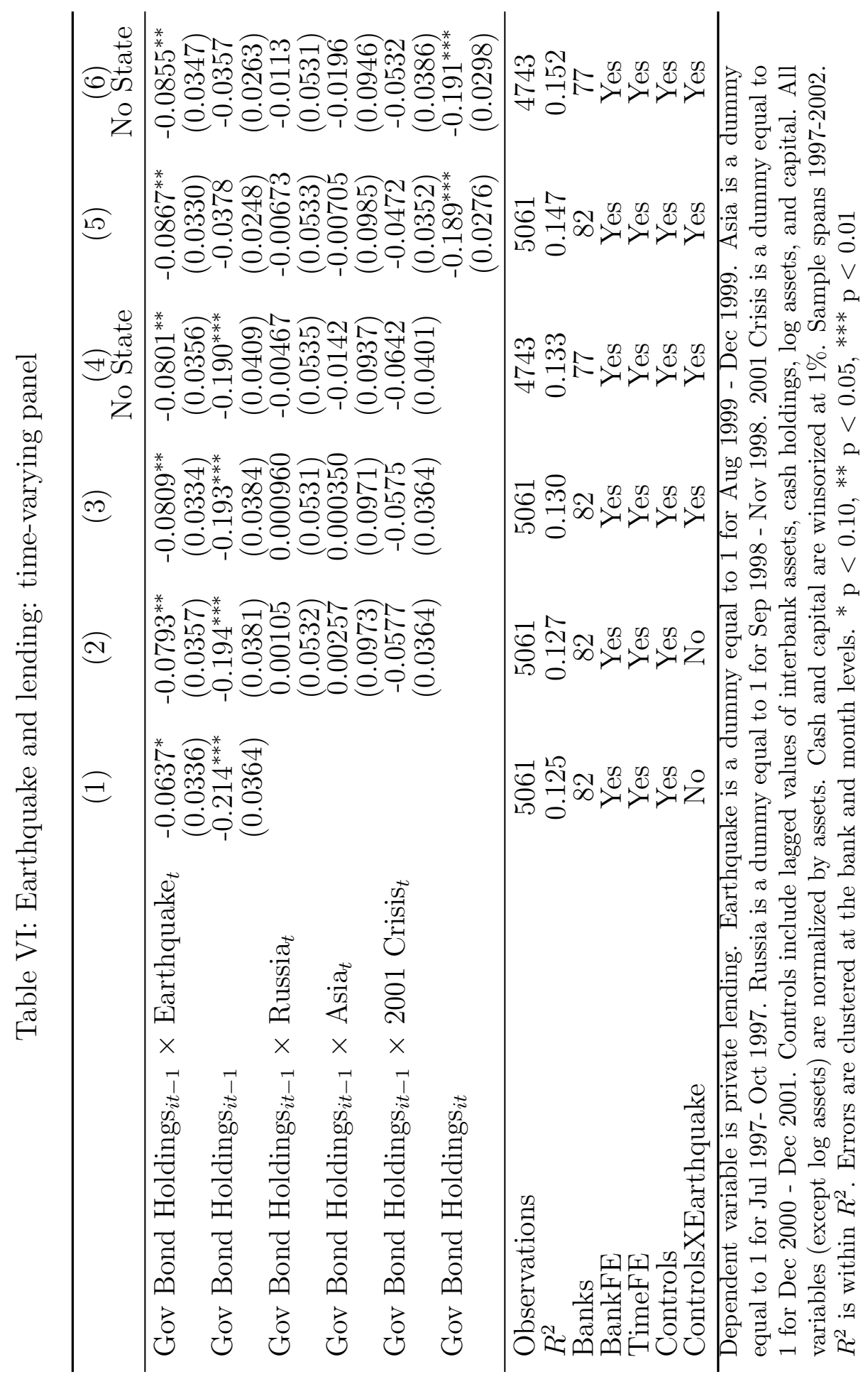




\section{$C \quad$ The Role of Sovereign Bond Yields}

The impact of the earthquake works through its impact on increasing the sovereign yields, which drive the value of the bonds down. This subsection quantifies the impact of an increase in sovereign yields on private lending, given the banks' government bond exposure. Specifically, we employ the same regression structure as before, but interact the yield with holdings (instead of earthquake and other crises).

$$
L_{i t}=\alpha_{i}+\alpha_{t}+\theta_{0} \text { Gov Debt Exp } \text { it-1 }_{i t}+\theta_{1} \text { GovDebtExp } \operatorname{Ex}_{i t-1} \times \text { Yield }_{t}+X_{i t-1} \Gamma+\epsilon_{i t}
$$

The Yield is the 3-month yield on Turkish government debt. ${ }^{21}$ However, the yield is endogenous to macroeconomic conditions that can also affect bank health, loan demand, etc. The health of the banking sector itself can affect sovereign yields. Thus, we exploit the earthquake to construct an instrumental variable (IV) to help us analyze the impact of rising yields. The first stage regression of the IV approach is:

$$
\begin{aligned}
\text { GovDebtExp }_{i t-1} \times \text { Yield }_{t}=\alpha_{i}+ & \alpha_{t}+\theta_{1} \text { Gov Debt Exp } \text { Ex-1 }_{i t-1} \\
& +\theta_{2} \text { GovDebtExp } p_{i t-1} \times \text { Earthquake }_{t}+X_{i t-1} \Gamma+\epsilon_{i t}
\end{aligned}
$$

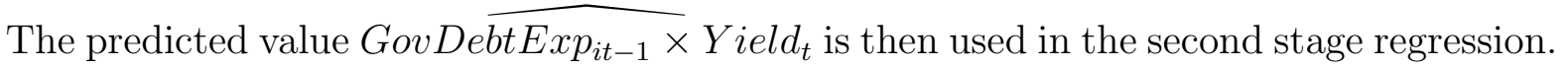

Turning to the results, we first examine the OLS relationship. Column 1 of Table VII reveals that there is no clear relationship over this period between the yield and lending, given the sovereign bond exposure. This highlights the endogenous nature of the sovereignbank nexus and the importance of finding exogenous variation to estimate causal impacts in one direction. Column 2 removes the general effect and adds interactions with the different

\footnotetext{
${ }^{21}$ This series is not continuously available. When it is missing, we use the 2-year yield, which is similar, and interpolate.
} 
shock periods. This is equivalent to replacing the dummies defining the shock periods with the value of the yield during those periods. This reveals that the earthquake period is the main period where we see a strong, negative connection between the yield and lending via bond holdings. Adding the direct effect back in for column 3 confirms this. Thus, the earthquake period shows the expected relationship in OLS for sovereign risk to affect bank lending via the balance sheet channel.

Table VII: Earthquake, Yield and Lending

\begin{tabular}{|c|c|c|c|}
\hline & (1) & $(2)$ & (3) \\
\hline Gov Bond Holdings $s_{i t-1} \times$ Yield $_{t}$ & $\begin{array}{l}-0.0769 \\
(0.0930)\end{array}$ & & $\begin{array}{c}-0.0613 \\
(0.100)\end{array}$ \\
\hline Gov Bond Holdings $s_{i t-1}$ & $-0.171^{* *}$ & $-0.198^{* * *}$ & $-0.164^{* *}$ \\
\hline Gov Bond Holdings $_{i t-1} \times$ Yield $_{t} \times$ Earthquake $_{t}$ & $(0.0696)$ & $\begin{array}{l}(0.0385) \\
-0.102^{* *} \\
(0.0477)\end{array}$ & $\begin{array}{c}-0.0874^{*} \\
(0.0454)\end{array}$ \\
\hline Gov Bond Holdings Hit-1 $\times$ Yield $_{t} \times$ Asia $_{t}$ & & & \\
\hline & & $\begin{array}{l}0.00355 \\
(0.0504)\end{array}$ & \\
\hline Gov Bond Holdings $_{i t-1} \times$ Yield $_{t} \times 2001$ Crisis $_{t}$ & & $\begin{array}{l}-0.0737 \\
(0.0558)\end{array}$ & $\begin{array}{l}-0.0614 \\
(0.0644)\end{array}$ \\
\hline Observations & 5059 & 5059 & 5059 \\
\hline$R^{2}$ & 0.126 & 0.127 & 0.128 \\
\hline Banks & 82 & 82 & 82 \\
\hline $\mathrm{FE}$ & Yes & Yes & Yes \\
\hline $\mathrm{FE}$ & Yes & $\mathrm{Ye}$ & Ye \\
\hline Controls & Yes & Yes & Yes \\
\hline \multicolumn{4}{|c|}{$\begin{array}{l}\text { Dependent variable is private lending. Yield is the yield on } 3 \text { month government bonds (or when } \\
\text { missing, the yield on } 2 \text { year government bonds). Controls include lagged values of interbank assets, } \\
\text { cash holdings, log assets, and capital. All variables (except log assets) are normalized by assets. } \\
\text { Cash and capital are winsorized at } 1 \% \text {. Earthquake is a dummy equal to } 1 \text { for Aug } 1999-\text { Dec } \\
1999 \text {. Asia is a dummy equal to } 1 \text { for Jul } 1997-\text { Oct } 1997 \text {. Russia is a dummy equal to } 1 \text { for } \\
\text { Sep } 1998-\text { Nov } 1998.2001 \text { Crisis is a dummy equal to } 1 \text { for Dec } 2000-\text { Dec } 2001 \text {. Sample spans } \\
1997-2002 . R^{2} \text { is within } R^{2} \text {. Errors are clustered at the bank and month levels. }{ }^{*} \text { p }<0.10,{ }^{* *} \text { p } \\
<0.05, * * * p<0.01\end{array}$} \\
\hline
\end{tabular}

To examine the causal impact, Table VIII presents the results of the IV regression. The first stage regression in the top half of the table shows that the earthquake is a significant predictor of the yield (both interacted with bond holdings), along with a reasonable Fstatistic. Thus, the instrument appears to be relevant and sufficiently strong. We have argued above that the earthquake is exogenous and materially impacted only sovereign risk, 
but not bank health except through sovereign risk, so it is plausibly excludable. ${ }^{22}$ We have also previously shown that government bond holdings of the banks did not adjust around the time of the earthquake, and the earthquake was unanticipated, so the lagged holdings can be taken as given. Column 1 shows that an increase in government bond yields is associated with a larger decline in bank lending for banks with greater exposure to government bonds. This estimate represents the local average treatment effect (LATE) of yield movements induced by the exogenous fiscal shock due to the earthquake. Column 2 shows this is robust to dropping state-owned banks. Columns 3 and 4 add bank-quarter fixed effects, which controls for slow moving bank-specific factors, including possibly loan demand (discussed more in the next section). This fixed effect saturation is quite a conservative and restrictive specification as it may soak up additional relevant variation in the data as well. Nevertheless, our IV results are robust to their inclusion.

These estimates suggest that the increase in sovereign bond yields has a significant impact on the lending. If the yield increased by one standard deviation over this period (27 pp), the estimate in column 1 implies a 2.8 percentage point decline in lending to assets ratio for a bank with average bond holdings (18\% of assets in 1999). For the earthquake itself (with a 6.8 percentage point increase in the yield from July to September 1999), the impact is a 0.7 percentage point decline in lending to assets for the average bank, $0.9 \mathrm{pp}$ for the 75th percentile bank (with $24 \%$ exposure in 1999), and 1.6 percentage point for the 90th percentile (with $40 \%$ exposure). To make these figures more accessible, our local average treatment effect suggests that 10 percentage point yield spike driven by fiscal shocks will cause a bank with $20 \%$ exposure to the shock to decrease its lending to assets ratio by 1.2 pp.

\footnotetext{
${ }^{22}$ We argue in Section $D$ below that loan demand did not differentially change across banks either.
} 
Table VIII: IV Regression: Spreads, bond holdings, and lending

\begin{tabular}{|c|c|c|c|c|}
\hline First Stage: LHS $=\mathrm{G}$ & $\begin{array}{l}\text { Bond } \mathrm{H} \\
(1)\end{array}$ & $\begin{array}{l}\underset{(2)}{\operatorname{sldings} \mathrm{X}} \\
\text { No State }\end{array}$ & $\begin{array}{l}\text { Field } \\
\qquad(3)\end{array}$ & No $\stackrel{(4)}{\text { State }}$ \\
\hline $\begin{array}{l}\text { Gov Bond Holdings } s_{i t-1} \times \text { Earthquake }_{t} \\
\text { Gov Bond Holdings } \\
i t-1\end{array}$ & $\begin{array}{l}0.112^{* * *} \\
(0.0388) \\
0.609^{* * *} \\
(0.0268)\end{array}$ & $\begin{array}{c}0.108^{* * *} \\
(0.0398) \\
0.615 \\
(0.0292)\end{array}$ & $\begin{array}{l}0.122^{* * *} \\
(0.0383) \\
0.614^{* * *} \\
(0.0352)\end{array}$ & $\begin{array}{l}0.122^{* * *} \\
(0.0382) \\
0.608^{* * *} \\
(0.0369)\end{array}$ \\
\hline F-Stat & 8.32 & 7.33 & 10.17 & 10.24 \\
\hline \multicolumn{5}{|c|}{ Second Stage: LHS $=$ Private Lending } \\
\hline $\begin{array}{l}\text { Gov Bond Holdings } \mathrm{s}_{i t-1} \times \text { Yield }_{t} \\
\text { Gov Bond Holdings } \\
i t-1\end{array}$ & $\begin{array}{c}-0.578^{*} \\
(0.321) \\
0.138 \\
(0.207) \\
\end{array}$ & $\begin{array}{c}-0.612^{*} \\
(0.351) \\
0.164 \\
(0.231) \\
\end{array}$ & $\begin{array}{c}-0.276^{*} \\
(0.148) \\
0.150 \\
(0.0963) \\
\end{array}$ & $\begin{array}{c}-0.316^{* *} \\
(0.154) \\
0.177^{*} \\
(0.0999) \\
\end{array}$ \\
\hline $\begin{array}{l}\text { Observations } \\
\text { Banks } \\
\text { BankFE } \\
\text { TimeFE } \\
\text { BankQuarterFE } \\
\text { Controls }\end{array}$ & $\begin{array}{l}5059 \\
82 \\
\text { Yes } \\
\text { Yes } \\
\text { No } \\
\text { Yes }\end{array}$ & $\begin{array}{l}4741 \\
77 \\
\text { Yes } \\
\text { Yes } \\
\text { No } \\
\text { Yes }\end{array}$ & $\begin{array}{l}5042 \\
82 \\
\text { Yes } \\
\text { Yes } \\
\text { Yes } \\
\text { Yes }\end{array}$ & $\begin{array}{l}4724 \\
77 \\
\text { Yes } \\
\text { Yes } \\
\text { Yes } \\
\text { Yes }\end{array}$ \\
\hline $\begin{array}{l}\text { Dependent variable in the second stage is priv } \\
\text { mented by Gov Bond Holdings } \times \text { Earthquake. } \\
\text { cash holdings, and capital, the latter two win } \\
\text { assets. Sample spans } 1997-2012 \text {. Errors are cl } \\
* * \text { p }<0.05 \text {, *** p }<0.01\end{array}$ & istered at & e bank an & dings $\times$ & $* \mathrm{p}<0.10$ \\
\hline
\end{tabular}




\section{$D$ Alternative Explanations and Robustness}

We have shown that the exogenous shock due to the earthquake generated a larger hit on the net worth for banks holding more government bonds, and that those banks reduced their private lending after the earthquake. The parallel trends assumption holds, and we control for other bank balance sheet characteristics correlated with bond holdings to account for other channels. However, there may still be other explanations for the connection of sovereign debt holdings a decreased lending following the earthquake. In this section, we examine and test such alternatives, and provide other robustness for our main results.

First, one threat to our identification is that banks with large exposure to the government sovereign risk might also lend to riskier borrowers whose businesses may suffer due to the earthquake, or may be more exposed to borrowers negatively impacted by the earthquake. If this were the case, these banks' credit contraction would be driven by a deterioration in borrower quality or an increase in defaults by firms exposed to the earthquake, rather than through exposure to government bonds. However, neither at the aggregate nor at the average level were non-performing loans (NPLs) increasing during the earthquake period; on the contrary, they were on a decline as shown below in Figures 10 and 11 respectively.

We further test this in our regression framework in Table IX. In columns 1 and 2, we consider our main regressions on lending after dropping banks that were eventually taken over by the SDIF. Such banks may have underlying weaknesses which may have been exposed by the earthquake and thus have lower performance and lending afterwards. ${ }^{23}$ Dropping these banks leaves our main results unchanged or strengthened. Further, in columns 2-5, we put NPLs as the dependent variable in our regression. Here, we confirm that banks holding more sovereign debt did not see a disproportionate increase in NPLs compared to other banks, so increased counterparty risk for private lending due to the earthquake does not help explain

\footnotetext{
${ }^{23}$ Only 8 banks were taken over by SDIF in 1999. Note that if the claim "bad banks will fail anyway" is true and we fail to control for this, then a diff-in-diff strategy should not give us any result since this strategy identifies off of the relative difference between bad and good banks at the time of the earthquake. Time invariant differences of these banks with other banks are absorbed by the bank fixed effects.
} 


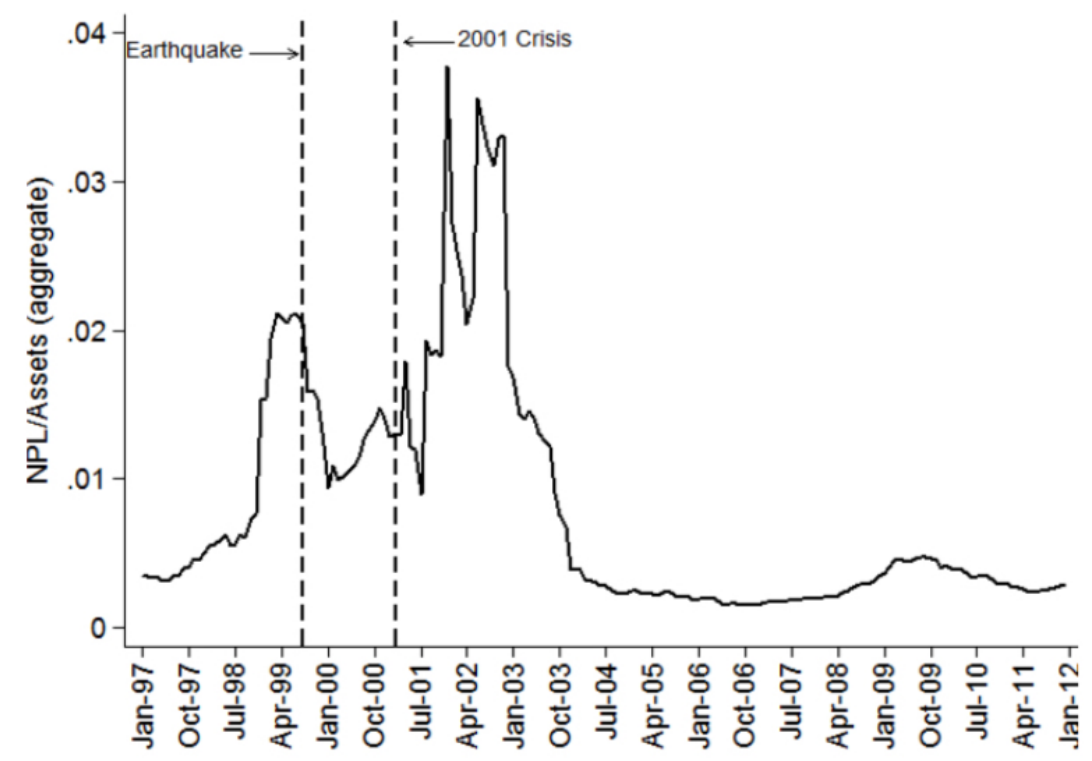

Figure 10: Non-performing Loans to Assets: Aggregate

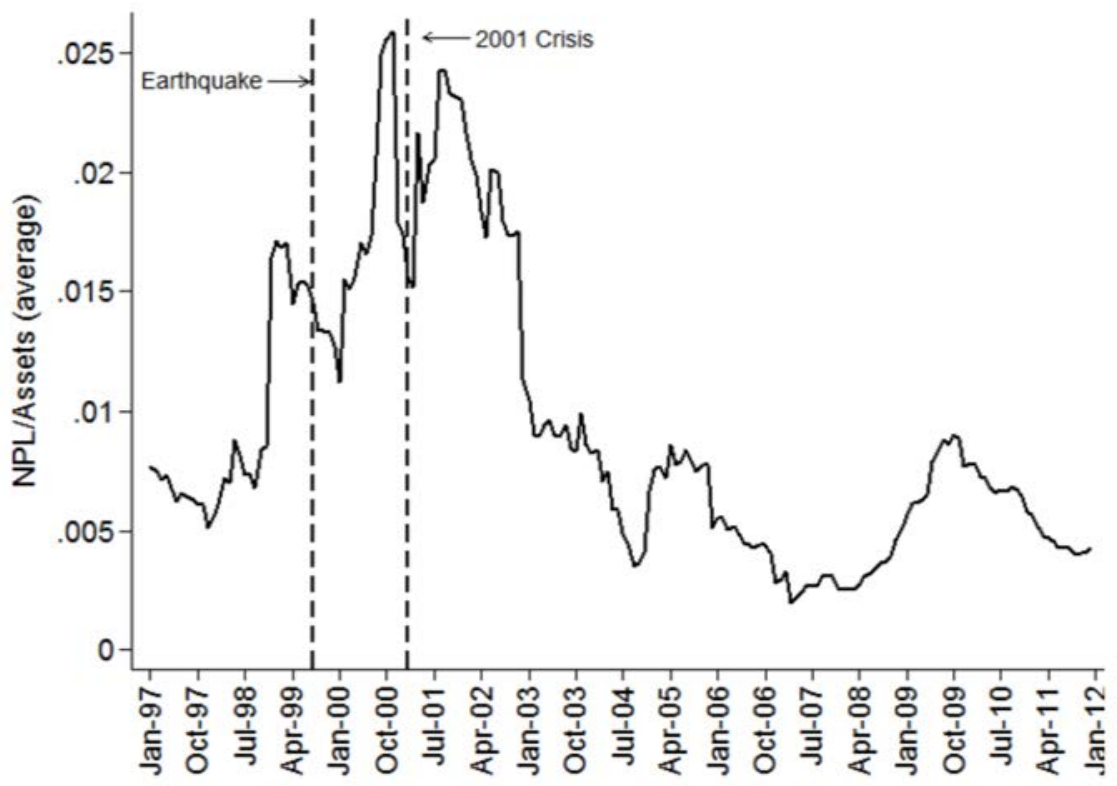

Figure 11: Non-performing Loans to Assets: Average 
the lending drop for banks holding more government bonds. $^{24}$

Table IX: Weak Banks and Risky Firms

\begin{tabular}{|c|c|c|c|c|c|}
\hline & \multicolumn{2}{|c|}{ Private Credit } & \multicolumn{3}{|c|}{ NPLs } \\
\hline & $\begin{array}{c}(1) \\
\text { No SDIF }\end{array}$ & $\begin{array}{c}(2) \\
\text { IV } \\
\text { No SDIF }\end{array}$ & $(3)$ & $(4)$ & $(5)$ \\
\hline Gov Bond Holdings ${ }_{i t-1} \times$ Earthquake $_{t}$ & $\begin{array}{c}-0.116^{* * *} \\
(0.0373)\end{array}$ & & $\begin{array}{c}0.00397 \\
(0.00421)\end{array}$ & $\begin{array}{c}0.00529 \\
(0.00413)\end{array}$ & $\begin{array}{c}0.00585 \\
(0.00444)\end{array}$ \\
\hline Gov Bond Holdings $_{i t-1} \times$ Yield $_{t}$ & & $\begin{array}{c}-0.798^{* * *} \\
(0.291)\end{array}$ & & & \\
\hline Gov Bond Holdings $\mathrm{s}_{i t-1}$ & $\begin{array}{c}-0.136^{* * *} \\
(0.0325)\end{array}$ & $\begin{array}{l}0.331^{*} \\
(0.182)\end{array}$ & $\begin{array}{c}0.217 \\
(0.00449)\end{array}$ & $\begin{array}{l}-0.00594 \\
(0.00485)\end{array}$ & $\begin{array}{l}-0.00590 \\
(0.00484)\end{array}$ \\
\hline Gov Bond Holdings ${ }_{i t-1} \times$ Russia $_{t}$ & $\begin{array}{l}-0.0521 \\
(0.0615)\end{array}$ & & & $\begin{array}{r}-0.000640 \\
(0.00611)\end{array}$ & $\begin{array}{r}-0.000646 \\
(0.00610)\end{array}$ \\
\hline Gov Bond Holdings $s_{i t-1} \times$ Asia $_{t}$ & -0.0136 & & & $\begin{array}{l}-0.00975 \\
(0.00897)\end{array}$ & -0.00973 \\
\hline Gov Bond Holdings $_{i t-1} \times 2001$ Crisis $_{t}$ & $\begin{array}{c}0.0190 \\
(0.0437)\end{array}$ & & & $\begin{array}{c}0.00569 \\
(0.00594)\end{array}$ & $\begin{array}{c}0.00575 \\
(0.00595)\end{array}$ \\
\hline Observations & 3878 & 3876 & 5061 & 5061 & 5061 \\
\hline$R^{2}$ & 0.103 & & 0.104 & 0.105 & 0.106 \\
\hline Banks & 62 & 62 & 82 & 82 & 82 \\
\hline BankFE & Yes & Yes & Yes & Yes & Yes \\
\hline TimeFE & Yes & Yes & Yes & Yes & Yes \\
\hline Controls & Yes & Yes & Yes & Yes & Yes \\
\hline ControlsXEarthquake & Yes & Yes & No & No & Yes \\
\hline
\end{tabular}

Dependent variable is listed above the columns and expressed as a ratio to assets. NPLs are winsorized at $5 \%$. Earthquake is a dummy equal to 1 for Aug 1999 - Nov 1999. Asia is a dummy equal to 1 for Jul 1997- Oct 1997. Russia is a dummy equal to 1 for Sep 1998 - Nov 1998. 2001 Crisis is a dummy equal to 1 for Dec 2000 - Dec 2001. Controls include lagged values of interbank assets, cash holdings, log assets, and capital. All variables (except log assets) are normalized by assets. Cash and capital are winsorized at 1\%. Yield is the yield on 3 month government bonds (or when missing, the yield on 2 year government bonds). Sample spans 1997-2002. $R^{2}$ is within $R^{2}$. Errors are clustered at the bank and month levels. ${ }^{*} \mathrm{p}<0.10,{ }^{* *} \mathrm{p}<0.05,{ }^{* * *} \mathrm{p}<0.01$

Next, we consider changes in demand. For the period prior to 2003, there is no loan level data in Turkey, therefore we cannot control for loan demand via a Kwaja-Mian approach with firm-time fixed effects. However, we take a few other approaches to help rule out demand shocks correlated with sovereign debt holdings.

First, since our bank level data is monthly, we can use bank-quarter fixed effects, which capture slower moving changes in loan demand. ${ }^{25}$ This argument is supported by the loan

\footnotetext{
${ }^{24}$ This would be important if banks holding more bonds also had a loan portfolio that was more geographically concentrated on areas affected by the earthquake.

${ }^{25}$ This argument is based on the framework presented in the appendix, where we show that the bank-
} 
officer survey data provided by CBRT, as presented in Figure B1 in the Appendix. It shows that the loan officers rarely report a sudden change in the credit demand within a quarter, especially for the non-financial corporate sector which constitute the majority of bank loans. The survey which has been conducted regularly since 2005 suggests that firms' demand for loans move very slowly. We assume that this was also the case during the earthquake period. The fact that the firm-bank relationships in general have a sticky nature even in developed financial markets like the US supports this assumption. ${ }^{26}$ Hence, given the monthly nature of our bank level data, the bank-quarter fixed effects will absorb slow moving bank-specific demand. ${ }^{27}$ For instance, if a certain banks' clientele is located in the earthquake region, these effects will capture the clients' lower demand during the last quarter of 1999 . We can still identify the balance sheet effect thanks to the monthly data where the value of the bonds will be marked down and affect the banks' balance sheets quicker than the changes in demand.

Table B5 confirms this relationship. In column 1, we show the standard regression after adjusting the earthquake window to August-October 1999. The main reason for this alternative definition of the earthquake is that the government unexpectedly imposed a tax on banks' income on government securities holdings on November 26, 1999 to cover the fiscal burden due to the earthquake. We find our results become stronger with this adjustment. In columns 2 and 3, we add bank-quarter fixed effects (and drop SDIF takeover banks). The magnitude drops considerably, but remains significant at the $10 \%$ level. Nevertheless, including bank-quarter fixed effects is an extremely stringent exercise, which absorbs a significant amount of variation in the data and thus lowers the estimated coefficients. ${ }^{28} \mathrm{We}$ also show robustness to bank-quarter fixed effects in Tables VIII and B4.

quarter fixed effects can help in capturing the first order effect of customer $j$ on loans by bank $i$ at time $t$ $\left(\eta_{i j t}\right)$, even when we do not observe borrower level variation.

${ }^{26}$ For example, see Chodorow-Reich (2014).

${ }^{27}$ Lee, Lee, and Paluszynski (2022) control the demand for bank loans using fixed effects in their work on the effect of bank capital requirements.

${ }^{28}$ One should not expect all valid relationships to remain statistically significant and of the right magnitude after their inclusion. 
The earthquake could have led to geographic differences in demand for loans and demand for customer deposits, which would affect the overall lending in the economy and potentially confound our analysis. If the earthquake results in lower loan demand (as economic activity is disrupted) or higher deposit withdrawal (as customers draw down their financial resources to meet emergency needs (Kundu, Park, \& Vats, 2022)), banks with higher exposure to the earthquake region through their costumer bases may have decreased credit volumes regardless of their exposure to the government securities. Thus, it could be that the decline in lending by banks holding government bonds is due to these banks operating disproportionately in the affected region. ${ }^{29}$ We utilize province-level regional data on deposit and lending to test for differences in loan demand or deposit outflow for the affected region after the earthquake: ${ }^{30}$

$$
y_{p t}=\alpha_{p}+\alpha_{t}+\beta \text { EarthquakeRegion }_{p} \times \text { Earthquake }_{t}+\text { province }_{p} \times \text { trend }_{t}+\epsilon_{p t}
$$

The dependent variable is either share of the province $p$ in country-level total credit or total deposits year $t$. The specification controls for province fixed effects $\alpha_{p}$, year fixed effects $\alpha_{t}$, as well as allows for province level linear trends province $_{p} \times$ trend $_{t}$ as extra control variables. The parameter of interest is $\beta$, i.e. the coefficient on the interaction term between the earthquake period and the dummy variable that takes value of 1 for the provinces affected by the earthquake, namely Istanbul, Izmit (Kocaeli), Sakarya (Adapazari), Yalova, Bolu, Duzce, Bursa and Eskisehir. A negative and significant value for this parameter would imply that the loans or deposits in the earthquake region would have significantly higher decline than the other regions in the earthquake year, and so banks' geographic presence could be an explanatory factor for their post-earthquake performance.

The Table X presents the results. Columns 1 and 2 show that lending did not system-

\footnotetext{
${ }^{29}$ Nearly all banks in our sample are headquartered in the region of the Earthquake (such as Istanbul), so variation across headquarters locations is unlikely to drive differences in bank outcomes after the earthquake.

${ }^{30}$ Data on the geographic distribution of bank deposits or loans (e.g. from credit registry data) is not available during the Earthquake period. The province-level regional data comes from the Banks Association of Turkey.
} 
Table X: Credit and Deposit Dynamics by Province and Year

\begin{tabular}{lcccc}
\hline & $\begin{array}{c}(1) \\
\text { Credit }\end{array}$ & $\begin{array}{c}(2) \\
\text { Credit }\end{array}$ & $\begin{array}{c}(3) \\
\text { Deposit }\end{array}$ & $\begin{array}{c}(4) \\
\text { Deposit }\end{array}$ \\
\hline Earthquake Region $p \times$ Year 1999 & -0.021 & 0.069 & 0.111 & 0.203 \\
& $(0.157)$ & $(0.122)$ & $(0.136)$ & $(0.181)$ \\
\hline Observations & 2639 & 2639 & 3164 & 3164 \\
$R^{2}$ & 0.01 & 0.63 & 0.01 & 0.78 \\
Province FE & Yes & Yes & Yes & Yes \\
Time FE & Yes & Yes & Yes & Yes \\
Province Level Linear Trends & No & Yes & No & Yes \\
\hline The regressions use the annual data, by the end of each year, on credits for 1984- \\
2017 and deposit at the province level for 1981-2021. The dependent variables in \\
column (1) and (2) are the share of loans in each province $p$ at year $t$ in country level \\
aggregate. The dependent variables in column (3) and (4) are the share of deposit in \\
each province $p$ at year $t$ in country level aggregate. The variable of interest is the \\
interaction between Earthquake Year Dummy Variable $(1999)$ and the indicator that \\
takes 1 for the provinces located in the earthquake region(Istanbul, Izmit (Kocaeli), \\
Sakarya (Adapazari), Yalova, Bolu, Duzce, Bursa, Eskisehir) $R^{2}$ is within $R^{2}$. Errors \\
are clustered at the the province level. ${ }^{*}$ p $<0.10, * *$ p $<0.05, * * *$ p $<0.01$
\end{tabular}

atically differ after the earthquake for borrowers located in the affected region compared to borrowers located elsewhere. Thus, we do not see evidence for a geographic difference in loan demand based on the earthquake. This is consistent with evidence from Blickle, Hamerling, and Morgan (2022), which shows that natural disasters do not necessarily lead to decrease in loan demand.

Columns 3 and 4 of Table $\mathrm{X}$ show that deposits in the earthquake region were likewise not significantly different. This implies that there was no differential change in withdrawal (or addition) of customer deposits in the earthquake region.

Moving back to the bank-level data, we can examine the deposits channel for individual banks. Table XI shows that deposits did not differentially decline for banks holding more government bonds following the earthquake. In fact, if anything, deposits might have risen for these banks. Digging deeper, Table B9 shows that non-deposit liabilities, which are less tied to a specific geography as deposits, are the liabilities that decreased. These results hold in both levels and changes. Thus, these results do not support the hypothesis that the decline in lending is tied to a withdrawal of deposits, either in general or from customers in 
affected regions.

Table XI: Earthquake and Deposits - Bank-level

\begin{tabular}{|c|c|c|c|c|c|}
\hline & (1) & $(2)$ & $(3)$ & No $\stackrel{(4)}{\text { State }}$ & No $\stackrel{(5)}{\mathrm{SDIF}}$ \\
\hline Gov Bond Holdings $\mathrm{s}_{i t-1} \times$ Earthquake $_{t}$ & $\begin{aligned} 0.18 \\
0.08\end{aligned}$ & & & 0.115 & 0.0258 \\
\hline Gov Bond Holdings $s_{i t-1}$ & -0.00329 & 0.0681 & 0.0610 & 0.0727 & 0.00479 \\
\hline & $(0.0672)$ & $(0.0874)$ & $(0.0865)$ & $(0.0943)$ & $(0.0520)$ \\
\hline Gov Bond Holdings $s_{i t-1} \times$ Russia $_{t}$ & & $\begin{array}{c}0.0729 \\
(0.0952)\end{array}$ & $\begin{array}{c}0.0716 \\
(0.0968)\end{array}$ & $\begin{array}{c}0.0612 \\
(0.0988)\end{array}$ & $\begin{array}{l}-0.132^{* *} \\
(0.0598)\end{array}$ \\
\hline Gov Bond Holdings $s_{i t-1} \times$ Asia $_{t}$ & & 0.0558 & 0.0556 & 0.0334 & $-0.173^{* *}$ \\
\hline Gov Bond Holdings $_{i t-1} \times 2001$ Crisis $_{t}$ & & $\begin{array}{c}(0.140) \\
-0.212 \\
(0.132)\end{array}$ & $\begin{array}{c}(0.141) \\
-0.217 \\
(0.133)\end{array}$ & $\begin{array}{c}(0.141) \\
-0.264^{*} \\
(0.152)\end{array}$ & $\begin{array}{c}(0.0852) \\
0.0203 \\
(0.0553)\end{array}$ \\
\hline Observat & 5061 & 5061 & 5061 & 4744 & 3876 \\
\hline$R^{2}$ & 0.321 & 0.324 & 0.328 & 0.332 & 0.128 \\
\hline anks & 82 & 82 & 82 & 77 & 62 \\
\hline ankFE & Yes & Yes & $\mathrm{Ye}$ & Yes & Yes \\
\hline & Yes & $\mathrm{Ye}$ & & Yes & Yes \\
\hline & Yes & $\mathrm{Ye}$ & & Yes & Yes \\
\hline ControlsXEarthquake & No & No & Yes & Yes & Yes \\
\hline \multicolumn{6}{|c|}{$\begin{array}{l}\text { Dependent variable is deposits relative to assets. Earthquake is a dummy equal to } 1 \text { for Aug } 1999-\text { Nov } 1999 . \\
\text { Asia is a dummy equal to } 1 \text { for Jul } 1997-\text { Oct } 1997 \text {. Russia is a dummy equal to } 1 \text { for Sep } 1998-\text { Nov } 1998 \text {. } \\
2001 \text { Crisis is a dummy equal to } 1 \text { for Dec } 2000-\text { Dec } 2001 \text {. Controls include lagged values of interbank assets, } \\
\text { cash holdings, log assets, and capital. All variables (except log assets) are normalized by assets. Cash and } \\
\text { capital are winsorized at } 1 \% \text {. Sample spans } 1997-2002 . R^{2} \text { is within } R^{2} \text {. Errors are clustered at the bank and } \\
\text { month levels. }{ }^{*} \mathrm{p}<0.10,{ }^{* *} \mathrm{p}<0.05,{ }^{* * *} \mathrm{p}<0.01\end{array}$} \\
\hline
\end{tabular}

Another alternative explanation why banks holding more government bonds might decrease their private lending after the shock is financial repression. That is, banks that provided the government with funding may be leaned on to provide even more funding in the event of a shock. We test this in Table XII. We do not find evidence that banks holding more government debt increased their holdings of government debt after the earthquake.

Failing to find evidence for these plausible alternatives, we conclude that the earthquake reduced lending of banks holding government bonds via the net worth channel (balance sheet shock).

Lastly, we examine robustness of our regressions to different specifications of our model, timing of crises and effects, sample windows. First, Table B6 runs placebo tests, where we define a "Placebo Earthquake" as a binary variable equal to 1 between April 1999 and July 
Table XII: Earthquake and Repression Channel

\begin{tabular}{|c|c|c|c|c|c|}
\hline & (1) & $(2)$ & $(3)$ & No $\stackrel{(4)}{\text { State }}$ & No $\stackrel{(5)}{\mathrm{SDIF}}$ \\
\hline Gov Bond Holdings $_{i t-1} \times$ Earthquake $_{t}$ & $\begin{array}{l}-0.0382 \\
(0.0669)\end{array}$ & $\begin{array}{l}-0.0259 \\
(0.0684)\end{array}$ & $\begin{array}{l}-0.0307 \\
(0.0657)\end{array}$ & $\begin{array}{l}-0.0280 \\
(0.0680)\end{array}$ & $\begin{array}{l}-0.0345 \\
(0.0899)\end{array}$ \\
\hline Gov Bond Holdings ${ }_{i t-1}$ & $0.843^{* * *}$ & $0.826^{* * *}$ & $0.825^{* * *}$ & $0.807^{* * *}$ & $0.822^{* * *}$ \\
\hline Gov Bond Holdings ${ }_{i t-1} \times$ Russia $_{t}$ & $(0.0270)$ & $\begin{array}{c}(0.0306) \\
-0.0406 \\
(0.0361)\end{array}$ & $\begin{array}{c}(0.0308) \\
-0.0408 \\
(0.0362)\end{array}$ & $\begin{array}{c}(0.0311) \\
-0.0345 \\
(0.0357)\end{array}$ & $\begin{array}{c}(0.0386) \\
-0.0524 \\
(0.0395)\end{array}$ \\
\hline Gov Bond Holdings $_{i t-1} \times$ Asia $_{t}$ & & $\begin{array}{c}-0.0394^{* * *} \\
(0.0119)\end{array}$ & $\begin{array}{c}-0.0393^{* * *} \\
(0.0121)\end{array}$ & $\begin{aligned}-0.0281^{* *} \\
(0.0116)\end{aligned}$ & $\begin{array}{l}-0.0297 \\
(0.0393)\end{array}$ \\
\hline Gov Bond Holdings $_{i t-1} \times 2001$ Crisis $_{t}$ & & $\begin{array}{c}0.0548 \\
(0.0345) \\
\end{array}$ & $\begin{array}{c}0.0545 \\
(0.0346)\end{array}$ & $\begin{array}{c}0.0575 \\
(0.0361) \\
\end{array}$ & $\begin{array}{r}0.00319 \\
(0.0407) \\
\end{array}$ \\
\hline Observations & 5061 & 5061 & 5061 & 4743 & 3878 \\
\hline$R^{2}$ & 0.712 & 0.713 & 0.714 & 0.689 & 0.677 \\
\hline Banks & 82 & 82 & 82 & 77 & 62 \\
\hline BankFE & Yes & Yes & Yes & Yes & Yes \\
\hline TimeFE & Yes & Yes & Yes & Yes & Yes \\
\hline Controls & Yes & Yes & Yes & Yes & Yes \\
\hline ControlsXEarthquake & No & No & Yes & Yes & Yes \\
\hline
\end{tabular}

Dependent variable is contemporaneous holdings of government bonds (relative to assets). Earthquake is a dummy equal to 1 for Aug 1999 - Nov 1999. Asia is a dummy equal to 1 for Jul 1997- Oct 1997. Russia is a dummy equal to 1 for Sep 1998 - Nov 1998. 2001 Crisis is a dummy equal to 1 for Dec 2000 - Dec 2001. Controls include lagged values of interbank assets, cash holdings, log assets, and capital. All variables (except $\log$ assets) are normalized by assets. Cash and capital are winsorized at 1\%. Sample spans 1997-2002. $R^{2}$ is within $R^{2}$. Errors are clustered at the bank and month levels. ${ }^{*} \mathrm{p}<0.10,{ }^{* *} \mathrm{p}<0.05,{ }^{* * *} \mathrm{p}<0.01$ 
1999. Despite the existence of a negative relation between high government debt exposure and lending in normal times, there is no additional effect at the time of our pseudo earthquake. This suggests that the effects we find with the earthquake are a result of the increased default risk on the part of government which deteriorated the balance sheet health of banks with high ex-ante exposure and hence negatively affected their lending.

Next, Table B7 examines alternative timings for the bond exposure. Column 1 uses a time invariant measure of bond holdings, the average of bond holdings over Jan 1997-Jul 1999. Since the bond holdings are fixed, we restrict the time period to a shorter window (1999-2000). In columns 2-3, we use the time varying bond holdings lagged by two periods. And in columns 4-5, we use time varying bond holdings lagged by three periods. Results remain robust and similar or larger in magnitude.

And finally, Table B8 examine the sample window more generally, as well as an alternative dependent variable. Columns 1 and 2, show the results with narrower and narrower windows around the earthquake. Columns 3-5 change the dependent variable to the change in lending. While the fixed effect specification naturally examines the change in lending (i.e. deviations from bank specific means), the results nevertheless hold when we examine the change in lending with those same fixed effects. Columns 4-5 show this specification for a narrowing sample window too. ${ }^{31}$

\section{Conclusion}

The "diabolic loop" between sovereign and bank credit risk was at the center of the 2009-2012 sovereign debt crisis in the periphery of the euro area. In Greece, Ireland, Italy, Portugal, and Spain, the deterioration of sovereign creditworthiness reduced the value of banks' holdings of domestic sovereign debt. Bank and sovereign CDS spreads started to move together. The presumed solvency of domestic banks was reduced, which directly impacted their lending

\footnotetext{
${ }^{31}$ Note that the 2001 crisis still has an estimated coefficient with the 1999-2000 sample because this crisis starts in Dec 2000.
} 
activity. The resulting bank distress increased the chances that banks would have to be bailed out by their own government, which increased sovereign distress even further. There is broad agreement on the policy urgency for the break-up of this vicious circle or doom loop/diabolic loop. ${ }^{32}$ The Covid-19 pandemic posed another threat on the stability of sovereign debt market for both advanced and emerging economies. Due to the unprecedented scale of the public health crisis, many countries had to increase public spending at a time of lower economic activity. ${ }^{33}$ As a result, sovereign default risks are on the rise and point again to the importance of understanding the "diabolic loop" between sovereign and bank credit risk.

In this paper, we identify the effect of government debt on banks' balance sheet health and credit provision. We provide a theoretical model to illustrate how a shock to the value of government debt can generate a heterogeneous decrease in banks lending along the lines of their holdings of government debt. We use data from the universe of banks in Turkey during 1997-2002 to demonstrate the financial constraint on banks and identify and quantify the impact of a sovereign shock on the banking sector. For identification, we use a rare disaster, the 1999 Marmara Earthquake - one of the largest earthquakes in world history, as a major unanticipated fiscal shock. Using a differences-in-differences methodology, we investigate whether the differences in the degree of banks' exposure to government debt matter for the effect of fiscal shock on differences in outcomes, such us banks' balance sheet health and loan provision.

Our empirical results validate the models formulation, showing that banks suffered valuation losses and their net worth fell, tightening their financial constraint and lending them to reduce their lending. We provide causal evidence for this balance sheet channel on lending, as high government debt exposure during the earthquake resulted in lower private lending than similar banks with low exposure, including by driving up government yields. We quantify these effects, estimating that exposure to sovereign debt accounted for nearly half of the observed lending decline following the earthquake. We demonstrate that the evidence does

\footnotetext{
${ }^{32}$ See Farhi and Tirole (2018); Brunnermeier et al. (2016).

${ }^{33}$ See Arellano, Bai, and Mihalache (2021) and Hardy and Zhu (2023)
} 
not support alternative explanations (e.g. demand shocks) of these patterns.

Our results provide evidence on the link between fiscal distress and financial imbalances, where the causality goes from fiscal to financial stress, impacting the real sector. Using an exogenous rare event which triggered a fiscal shock and an increase in sovereign risk, we identify that the fiscal imbalances has important causal implications for the performance of the financial sector and credit provision. These results are important for policy, particularly in the context of the large increase in government debt due to the Covid-19 pandemic.

Although our identification is clear, valid, and policy relevant, it works only for the link from government debt to banks' balance sheet health and loan provision. It does not capture the feedback of bank risk back to the sovereign or account for any general equilibrium amplification of the shock due to fire sales or cliff effects in the financial sector. Hence, our results are important for one direction of the sovereign-bank doom loop, but leave the equally important task of identifying the impact of a banking crisis on sovereign defaults to future research. 


\section{References}

Acharya, V., Drechsler, I., \& Schnabl, P. (2014). A pyrrhic victory? bank bailouts and sovereign credit risk. Journal of Finance, 69, 2689-2739.

Acharya, V., Eisert, T., Eufinger, C., \& Hirsch, C. (2019). Whatever it takes: The real effects of uncoventional monetary policy. Review of Financial Studies, 32(9), 3366-3411.

Aguiar, M., \& Amador, M. (2014). Chapter 11 - sovereign debt. In G. Gopinath, E. Helpman, \& K. Rogoff (Eds.), Handbook of international economics (Vol. 4, p. 647-687). Elsevier.

Akgiray, V., Barbarosoglu, G., \& Erdik, M. (2004). The 1999 marmara earthquakes in turkey. OECD Publishing.

Altavilla, C., Pagano, M., \& Simonelli, S. (2015). Banks exposures and sovereign stress transmission. Review of Finance, 21 (6), 2103-2139.

Arellano, C., Bai, Y., \& Bocola, L. (2020). Sovereign default risk and firm heterogeneity. Working Paper.

Arellano, C., Bai, Y., \& Mihalache, G. (2021). Deadly debt crises: Covid-19 in emerging markets.

Arteta, C., \& Hale, G. (2008). Sovereign debt crises and credit to the private sector. Journal of International Economics, 74, 53-69.

Becker, B., \& Ivashina, V. (2014). Cyclicality of credit supply: Firm level evidence. Journal of Monetary Economics, 62, 76-93.

Blickle, K., Hamerling, S., \& Morgan, D. (2022). How bad are weather disasters for banks? New York Federal Reserve Staff Reports, No 990.

Bocola, L. (2016). The Pass-Through of Sovereign Risk. Journal of Political Economy, $124(4), 879-926$.

Bofondi, C. L., Mark, \& Sette, E. (2018). Credit supply during a sovereign debt crisis. Journal of the European Economic Association, 16(3), 696-729.

Brunnermeier, M. K., Garicano, L., Lane, P. R., Pagano, M., Reis, R., Santos, T., ... Vayanos, D. (2016). The sovereign-bank diabolic loop and esbies. American Economic Review, $106(5), 508-12$. 
Buch, C. M., Koetter, M., \& Ohls, J. (2016). Banks and sovereign risk: A granular view. Journal of Financial Stability, 25, 1-15.

Chodorow-Reich, G. (2014). The employment effects of credit market disruptions: Firmlevel evidence from the 2008-09 financial crisis. Quarterly Journal of Economics, 129, $1-59$.

De Marco, F. (2019). Bank lending and the european sovereign debt crisis. Journal of Financial and Quantitative Analysis, 54(1), 155-182.

Dervis, K., Gros, D., Oztrak, F., Bayar, F., \& Isik, Y. (2004). Stabilising stabilisation. Centre for European Policy Studies EU-Turkey Working Papers, No. 7.

Fang, X., Hardy, B., \& Lewis, K. (2022). Who holds sovereign debt and why it matters. NBER Working Paper, No 30087.

Farhi, E., \& Tirole, J. (2018). Deadly embrace: Sovereign and financial balance sheets doom loops. Review of Economic Studies, 85(3), 1781-1823.

Gennaioli, N., Martin, A., \& Rossi, S. (2014). Sovereign default, domestic banks, and financial institutions. Journal of Finance, 69, 819-866.

Gennaioli, N., Martin, A., \& Rossi, S. (2018). Banks, government Bonds, and Default: What do the data Say? Journal of Monetary Economics, 98(C), 98-113.

Gertler, M., \& Karadi, P. (2011). A model of unconventional monetary policy. Journal of Monetary Economics, 58(1), 17-34.

Gilchrist, S., Wei, B., Yue, V., \& Zakrajšek, E. (2022). Sovereign risk and financial risk. Journal of International Economics, 136.

Hardy, B., \& Zhu, S. (2023). Covid, central banks and the bank-sovereign nexus. BIS Quarterly Review, March, 55-69.

Kundu, S., Park, S., \& Vats, N. (2022). The geography of bank deposits and the origins of aggregate fluctuations. mimeo.

Lee, H., Lee, S., \& Paluszynski, R. (2022). Capital regulation and shadow finance: A quantitative analysis. Working Paper.

Morelli, J. M., Ottonello, P., \& Perez, D. J. (2022). Global banks and systemic debt crises. 
Econometrica, 90(2), 749-798.

Özatay, F., \& Sak, G. (2002). Banking sector fragility and turkey's 2000-01 financial crisis. Brookings Trade Forum, 121-172.

Popov, A., \& Van Horen, N. (2015). Exporting sovereign stress: Evidence from syndicated bank lending during the euro area sovereign debt crisis. Review of Finance, 19(5), $1825-1866$.

Reinhart, C. M., \& Rogoff, K. (2009). This time is different: Eight centuries of financial folly. Princeton University Press.

Tomz, M., \& Wright, M. (2013). Empirical research on sovereign debt and default. NBER Working Paper.

Wei, B., \& Yue, V. (2019). Sovereign debt - theory. Oxford Research Encyclopedia of Economics and Finance, November. 


\section{Appendix}

\section{A Summary Statistics}

Table A1: Descriptive Statistics

\begin{tabular}{lccccccc}
\hline & count & mean & $\mathrm{sd}$ & $\mathrm{p} 25$ & $\mathrm{p} 50$ & $\mathrm{p} 75$ & $\mathrm{p} 90$ \\
\hline Gov Bond Holdings & 5153 & 0.1824 & 0.1566 & 0.0690 & 0.1436 & 0.2451 & 0.3975 \\
Capital Ratio & 5153 & 0.1678 & 0.2511 & 0.0742 & 0.1172 & 0.2306 & 0.5022 \\
Loans to Non-Financial Sector & 5153 & 0.2709 & 0.1779 & 0.1270 & 0.2644 & 0.3908 & 0.5063 \\
Non-Performing Loans & 5147 & 0.0091 & 0.0156 & 0.0000 & 0.0012 & 0.0096 & 0.0407 \\
Bank Size & 5153 & 12.1259 & 2.0483 & 10.6258 & 12.2497 & 13.5374 & 14.8369 \\
Cash Holdings & 5147 & 0.0083 & 0.0096 & 0.0005 & 0.0057 & 0.0124 & 0.0198 \\
Interbank Balances & 5147 & -0.0858 & 0.2824 & -0.2373 & -0.0601 & 0.0588 & 0.2234 \\
Valuation & 5095 & 0.1068 & 0.3529 & 0.0000 & 0.0000 & 0.0000 & 0.1652 \\
Profits & 5153 & 0.0121 & 0.0636 & 0.0010 & 0.0128 & 0.0348 & 0.0777
\end{tabular}

Sample spans 1997-2002. Gov Bond Holdings is defined as the bank's holdings of government bonds in ratio to Total Assets. Capital Ratio is defined as the ratio of Shareholder Equity to Total Assets. Loans to Non-Financial Sector is defined as Total Loans to Private Sector in ratio to Total Assets. NonPerforming Loans is defined as (Non-Performing Loans - Provisions on Non-Performing Loans) in ratio to Total Assets. Bank Size is defined as the log value of total assets deflated to 2000 USD using PPI. Cash Holdings is the banks cash holdings in ratio to total assets. Interbank Balances are defined as (Receivables-Payables) from banks (except the Central Bank), in ratio to Total Assets. Valuation is financial assets valuation difference (i.e. loss provision) as a ratio to total assets. Profits are the bank profits in ratio to total assets.

Table A2: Selected Macroeconomic Statistics (\%)

\begin{tabular}{lcc}
\hline & $1997-2002$ & $1997-2011$ \\
\hline Average Annual GDP Growth Rate & 2.50 & 4.29 \\
Average Investment to GDP Ratio & 20.55 & 22.19 \\
Credit to Private Sector to GDP & 15.30 & 19.60 \\
Bank Assets to GDP & 53.40 & 59.10 \\
Public Debt to GDP & 48.47 & 47.50 \\
& & \\
\hline
\end{tabular}

\section{B Further results}


Table A3: Loans to Private Sector and Government-Bond Holdings Before and After EQ

\begin{tabular}{lcc}
\hline & $\begin{array}{c}\text { Government- } \\
\text { bond holdings }\end{array}$ & $\begin{array}{c}\text { Loans to Private } \\
\text { Sector }\end{array}$ \\
\hline April-July 1999 Average & 18.7 & 26.8 \\
August-October 1999 Average & 19.0 & 24.8 \\
\hline
\end{tabular}

Note: Measures are expressed as a percent of Total Assets. 


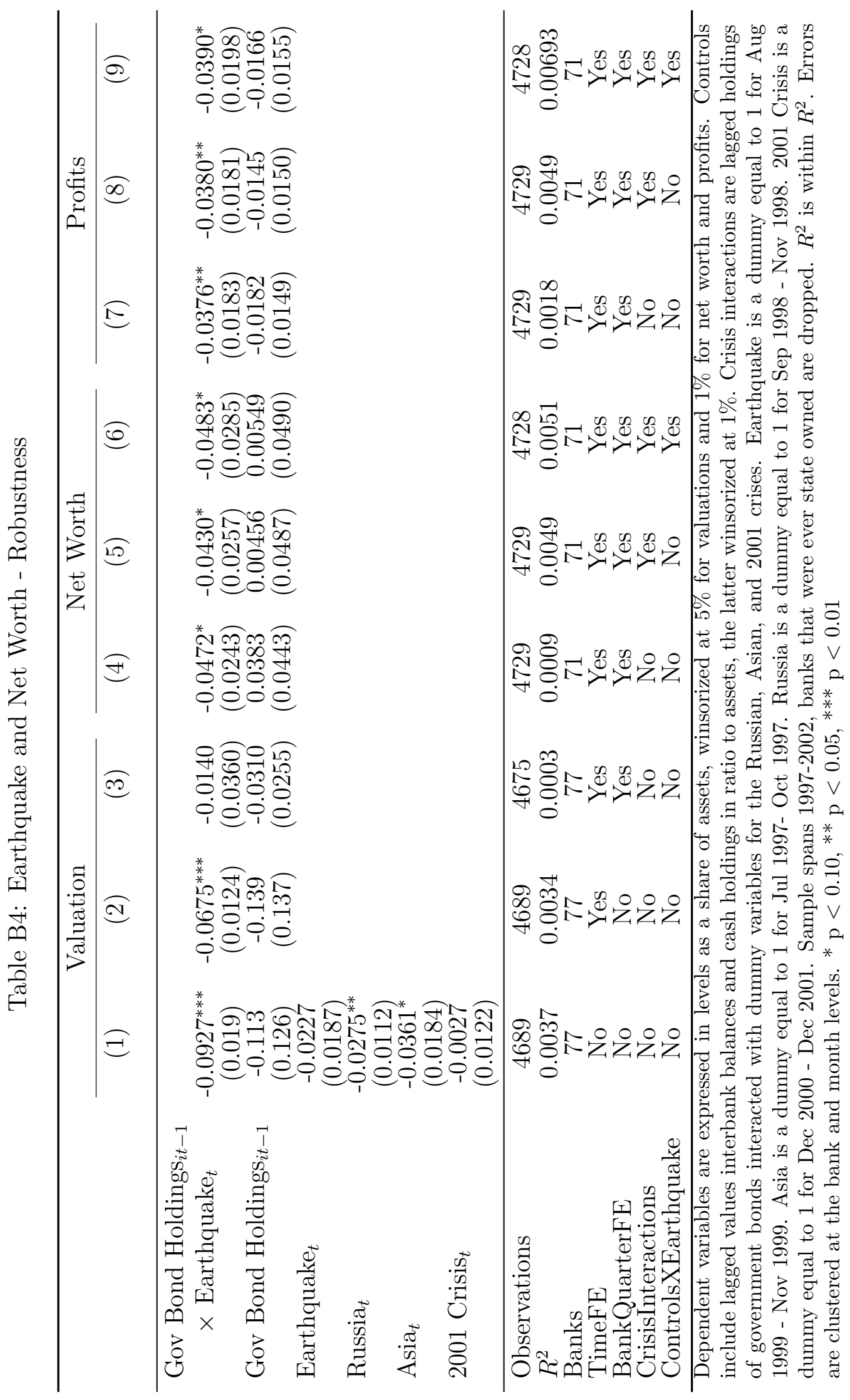




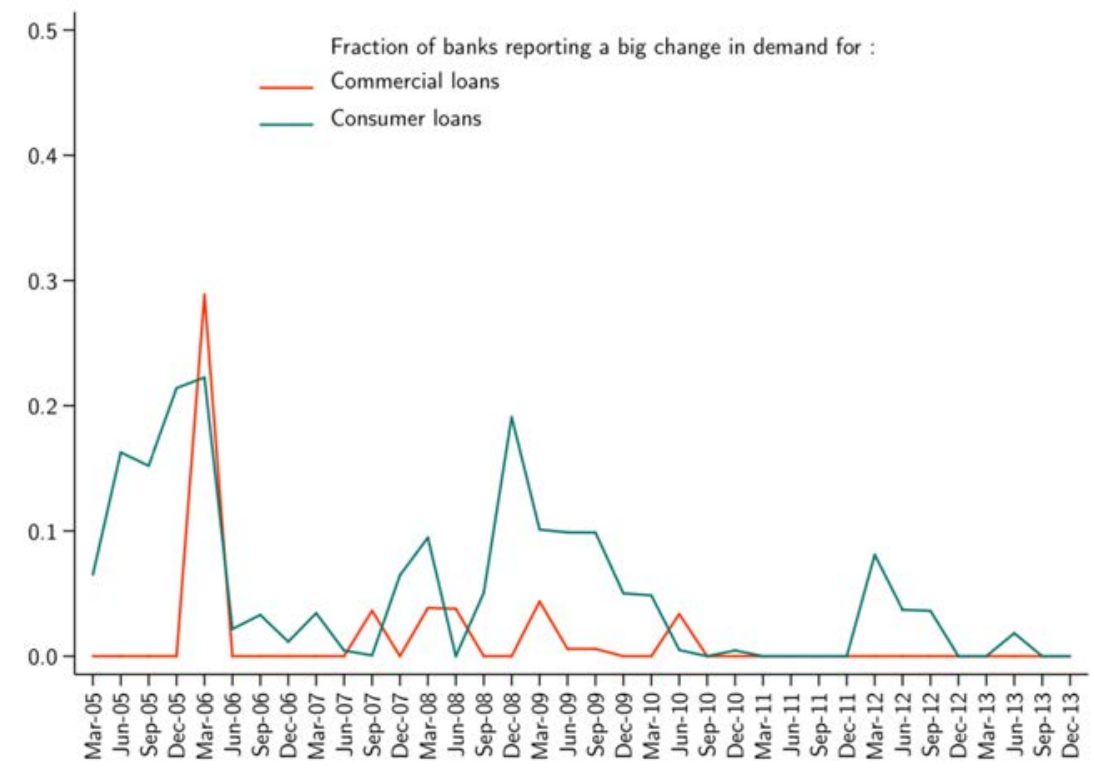

Figure B1: Ratio of Banks Reporting a Sudden Change in Loan Demand - CBRT Loan Officer Survey 


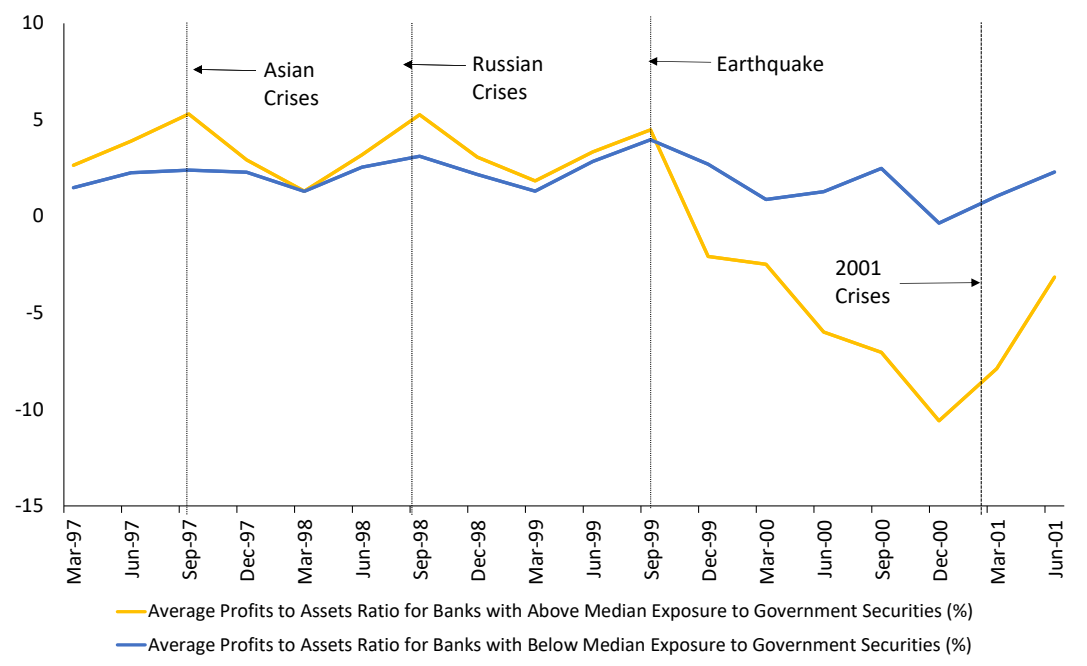

Figure B2: Profits of Banks with High-Low Exposure to Government Bond Market Table B5: Earthquake and lending: Bank-Quarter Fixed Effects

\begin{tabular}{|c|c|c|c|c|}
\hline & (1) & $(2)$ & No $\stackrel{(3)}{\text { State }}$ & No $\stackrel{(4)}{\text { SDIF }}$ \\
\hline Gov Bond Holdings $_{i t-1} \times$ Earthquake $_{t}$ & $\begin{array}{l}-0.0989^{* * *} \\
(0.0326)\end{array}$ & $\begin{array}{r}-0.0332^{*} \\
(0.0190)\end{array}$ & $\begin{array}{l}-0.0352^{*} \\
(0.0208)\end{array}$ & $\begin{array}{l}-0.0276^{*} \\
(0.0140)\end{array}$ \\
\hline Gov Bond Holdings $\mathrm{s}_{i t-1}$ & $-0.198^{* * *}$ & -0.00945 & -0.0103 & 0.00325 \\
\hline & $(0.0385)$ & $(0.0139)$ & $(0.0150)$ & $(0.0145)$ \\
\hline Gov Bond Holdings $_{i t-1} \times$ Russia $_{t}$ & -0.0650 & -0.0107 & -0.0189 & 0.0104 \\
\hline Gov Bond Holdings ${ }_{i t-1} \times 2001$ Crisis $_{t}$ & $\begin{array}{c}-0.0538 \\
(0.0367)\end{array}$ & $\begin{array}{c}-0.0456^{* *} \\
(0.0225)\end{array}$ & $\begin{array}{c}(0.0351) \\
-0.0356 \\
(0.0229)\end{array}$ & $\begin{array}{c}(0.0300) \\
-0.0306 \\
(0.0213)\end{array}$ \\
\hline Observations & 4290 & 4275 & 4012 & 3320 \\
\hline$R^{2}$ & 0.148 & 0.00571 & 0.00390 & 0.00562 \\
\hline Banks & 82 & 82 & 77 & 62 \\
\hline BankFE & Yes & Yes & Yes & Yes \\
\hline TimeFE & Yes & Yes & Yes & Yes \\
\hline Controls & Yes & Yes & Yes & Yes \\
\hline BankQuarterFE & No & Yes & Yes & Yes \\
\hline \multicolumn{5}{|c|}{$\begin{array}{l}\text { Dependent variable is private lending. Controls include log assets, interbank assets, cash holdings, } \\
\text { and capital, the latter two winsorized at } 1 \% \text {. All variables (except log assets) are as a ratio to total } \\
\text { assets. Earthquake is a dummy equal to } 1 \text { for Aug } 1999 \text { - Oct } 1999 \text {. Russia is a dummy equal to } 1 \\
\text { for Sep } 1998 \text { - Nov 1998. } 2001 \text { Crisis is a dummy equal to } 1 \text { for Dec } 2000-\text { Dec } 2001 \text {. Sample spans } \\
\text { 1998-2002. Interaction with Asia dummy (Jul 1997- Oct } 1997 \text { ) is thus dropped. } R^{2} \text { is within } R^{2} \text {. } \\
\text { Errors are clustered at the bank and month levels. }{ }^{*} \mathrm{p}<0.10,{ }^{* *} \mathrm{p}<0.05,{ }^{* *} \mathrm{p}<0.01\end{array}$} \\
\hline
\end{tabular}


Table B6: Earthquake and lending: Placebo test

\begin{tabular}{|c|c|c|c|}
\hline & (1) & $(2)$ & $(3)$ \\
\hline Gov Bond Holdings $s_{i t-1}$ & $\begin{array}{c}-0.236^{* * *} \\
(0.0360)\end{array}$ & $\begin{array}{c}-0.219^{* * *} \\
(0.0368)\end{array}$ & $\begin{array}{c}-0.189^{* * *} \\
(0.0381)\end{array}$ \\
\hline Gov Bond Holdings $s_{i t-1} \times$ Placebo $_{t}$ & -0.00699 & -0.0200 & -0.0551 \\
\hline Gov Bond Holdings ${ }_{i t-1} \times$ Russia $_{t}$ & & & \\
\hline Gov Bond Holdings $s_{i t-1} \times$ Asia $_{t}$ & & $\begin{array}{l}-0.0205 \\
(0.101)\end{array}$ & $\begin{array}{r}-0.00249 \\
(0.0966)\end{array}$ \\
\hline Gov Bond Holdings $s_{i t-1} \times 2001$ Crisis $_{t}$ & & -0.0509 & \\
\hline Gov Bond Holdings $s_{i t-1} \times$ Earthquake $_{t}$ & & & $\begin{array}{c}-0.0855^{* *} \\
(0.0398)\end{array}$ \\
\hline Observations & 5069 & 5069 & 5061 \\
\hline$R^{2}$ & 0.0948 & 0.0962 & 0.127 \\
\hline Banks & 82 & 82 & 82 \\
\hline BankFE & Yes & Yes & Yes \\
\hline TimeFE & Yes & Yes & Yes \\
\hline Controls & No & No & Yes \\
\hline \multicolumn{4}{|c|}{$\begin{array}{l}\text { Dependent variable is private lending. Controls include lagged values of interbank } \\
\text { assets, cash holdings, log assets, and capital. All variables (except log assets) are } \\
\text { normalized by assets. Cash and capital are winsorized at } 1 \% \text {. Placebo takes a value } \\
\text { of } 1 \text { over April } 1999 \text { to July } 1999 \text {. Earthquake is a dummy equal to } 1 \text { for Aug } 1999 \\
\text { - Dec } 1999 \text {. Asia is a dummy equal to } 1 \text { for Jul } 1997 \text { - Oct } 1997 \text {. Russia is a dummy } \\
\text { equal to } 1 \text { for Sep } 1998-\text { Nov } 1998 \text {. } 2001 \text { Crisis is a dummy equal to } 1 \text { for Dec } 2000 \\
\text { - Dec } 2001 \text {. Sample spans } 1997-2002 . R^{2} \text { is within } R^{2} \text {. Errors are clustered at the } \\
\text { bank and month levels. }{ }^{*} \mathrm{p}<0.10,{ }^{* *} \mathrm{p}<0.05,{ }^{* * *} \mathrm{p}<0.01\end{array}$} \\
\hline
\end{tabular}


Table B7: Earthquake and lending: Timing Robustness

\begin{tabular}{|c|c|c|c|c|c|}
\hline & (1) & $(2)$ & $(3)$ & $(4)$ & $(5)$ \\
\hline Gov Bond Holdings $s_{i} \times$ Earthquake $_{t}$ & $\begin{array}{l}-0.164^{* *} \\
(0.0643)\end{array}$ & & & \multirow{11}{*}{$\begin{array}{c}-0.166^{* * *} \\
(0.0346)\end{array}$} & \multirow{7}{*}{$\begin{array}{r}-0.141^{* * *} \\
(0.0364)\end{array}$} \\
\hline Gov Bond Holdings $s_{i t-2}$ & & $\begin{array}{r}-0.191^{* * *} \\
(0.0356)\end{array}$ & $\begin{array}{r}-0.167^{* * *} \\
(0.0374)\end{array}$ & & \\
\hline Gov Bond Holdings ${ }_{i t-3}$ & & & & & \\
\hline Gov Bond Holdings ${ }_{i t-2} \times$ Earthquake $_{t}$ & & \multirow[t]{8}{*}{$\begin{array}{c}-0.0987^{* * *} \\
(0.0337)\end{array}$} & \multirow{8}{*}{$\begin{array}{c}-0.113^{* * *} \\
(0.0387) \\
0.00334 \\
(0.108) \\
-0.0260 \\
(0.0646) \\
-0.0452 \\
(0.0377)\end{array}$} & & \\
\hline Gov Bond Holdings $s_{i t-2} \times$ Asia $_{t}$ & & & & & \\
\hline Gov Bond Holdings ${ }_{i t-2} \times$ Russia $_{t}$ & & & & & \\
\hline Gov Bond Holdings ${ }_{i t-2} \times 2001$ Crisis $_{t}$ & & & & & \\
\hline Gov Bond Holdings $_{i t-3} \times$ Earthquake $_{t}$ & & & & & $\begin{array}{l}-0.106^{* *} \\
(0.0409)\end{array}$ \\
\hline Gov Bond Holdings $s_{i t-3} \times$ Asia $_{t}$ & & & & & $\begin{array}{l}-0.0650 \\
(0.0932)\end{array}$ \\
\hline Gov Bond Holdings ${ }_{i t-3} \times$ Russia $_{t}$ & & & & & -0.0480 \\
\hline Gov Bond Holdings $_{i t-3} \times 2001$ Crisis $_{t}$ & & & & & $\begin{array}{l}-0.0445 \\
(0.0403)\end{array}$ \\
\hline Observations & 1860 & 4895 & 4895 & 4814 & 4814 \\
\hline$R^{2}$ & 0.0172 & 0.118 & 0.164 & 0.105 & 0.156 \\
\hline Banks & 79 & 82 & 82 & 82 & 82 \\
\hline BankFE & Yes & Yes & Yes & Yes & Yes \\
\hline TimeFE & Yes & Yes & Yes & Yes & Yes \\
\hline Controls & Yes & Yes & Yes & Yes & Yes \\
\hline ControlsXCrises & Yes & Yes & Yes & Yes & Yes \\
\hline \multicolumn{6}{|c|}{$\begin{array}{l}\text { Dependent variable is private lending. In column 1, Gov Bond Holdings is time invariant, the average of holdings } \\
\text { (to assets) over Jan 1997-Jul 1999. Controls include log assets, interbank assets, cash holdings and capital, the } \\
\text { latter two winsorized at } 1 \% \text {. All variables (except log assets) are as a ratio to total assets. Earthquake is a } \\
\text { dummy equal to } 1 \text { for Aug } 1999 \text { - Dec } 1999 \text {. Asia is a dummy equal to } 1 \text { for Jul } 1997-\text { Oct } 1997 \text {. Russia is a } \\
\text { dummy equal to } 1 \text { for Sep } 1998-\text { Nov } 1998 \text {. } 2001 \text { Crisis is a dummy equal to } 1 \text { for Dec } 2000-\text { Dec } 2001 \text {. Sample } \\
\text { spans } 1997-2002 . R^{2} \text { is within } R^{2} \text {. Errors are clustered at the bank and month levels. }{ }^{*} \mathrm{p}<0.10,{ }^{* *} \mathrm{p}<0.05 \text {, } \\
* * * \mathrm{p}<0.01\end{array}$} \\
\hline
\end{tabular}


Table B8: Earthquake and lending: Robustness to sample period and lending measure

\begin{tabular}{|c|c|c|c|c|c|}
\hline & \multicolumn{2}{|c|}{ Lending } & \multicolumn{3}{|c|}{$\Delta$ Lending } \\
\hline & $1998-2001$ & $1999-2000$ & $1997-2002$ & $1998-2001$ & $1999-2000$ \\
\hline Gov Bond Holdings $s_{i t-1} \times$ Earthquake $^{2}$ & $-0.0876^{* * *}$ & $-0.134^{* * *}$ & $-0.0142^{*}$ & $-0.0170^{* *}$ & $-0.0219^{* *}$ \\
\hline Gov Bond Holdings $s_{i t-1}$ & $\begin{array}{l}(0.0325) \\
-0.231^{* * *}\end{array}$ & $\begin{array}{l}(0.0396) \\
-0.157^{* * *}\end{array}$ & $\begin{array}{l}(0.00750) \\
0.00704\end{array}$ & $\begin{array}{l}(0.00808) \\
0.0177^{* *}\end{array}$ & $\begin{array}{l}(0.00906) \\
0.0213^{* *}\end{array}$ \\
\hline Gov Bond Holdings $\mathrm{s}_{i t-1} \times$ Asia $_{t}$ & $(0.0435)$ & $(0.0553)$ & $\begin{array}{l}(0.00495) \\
-0.0168^{* *} \\
(0.00639)\end{array}$ & (0.00709) & $(0.00766)$ \\
\hline Gov Bond Holdings $s_{i t-1} \times$ Russia $_{t}$ & $\begin{array}{l}-0.0458 \\
(0.0554)\end{array}$ & & $\begin{array}{l}-0.0155 \\
(0.0212)\end{array}$ & $\begin{array}{l}-0.0260 \\
(0.0216)\end{array}$ & \\
\hline Gov Bond Holdings $_{i t-1} \times 2001$ Crisis $_{t}$ & $\begin{array}{l}-0.0216 \\
(0.0451)\end{array}$ & $\begin{array}{r}-0.00817 \\
(0.0180)\end{array}$ & $\begin{array}{l}-0.0180^{*} \\
(0.00911)\end{array}$ & $\begin{array}{c}-0.0263^{* *} \\
(0.0107)\end{array}$ & $\begin{array}{c}0.0154 \\
(0.00942)\end{array}$ \\
\hline Observations & 3629 & 1903 & 5057 & 3629 & 1903 \\
\hline$R^{2}$ & 0.164 & 0.166 & 0.0139 & 0.0178 & 0.00766 \\
\hline Banks & 82 & 82 & 82 & 82 & 82 \\
\hline BankFE & Yes & Yes & Yes & Yes & Yes \\
\hline TimeFE & Yes & Yes & Yes & Yes & Yes \\
\hline Controls & Yes & Yes & Yes & Yes & Yes \\
\hline
\end{tabular}

Dependent variable in columns 1-2 is private lending (over assets); in columns 3-5 is the change in private lending (over lagged assets). Controls include log assets, interbank assets, cash holdings, and capital, the latter two winsorized at $1 \%$. All variables (except log assets) are as a ratio to total assets. Earthquake is a dummy equal to 1 for Aug 1999 - Dec 1999. Asia is a dummy equal to 1 for Jul 1997- Oct 1997. Russia is a dummy equal to 1 for Sep 1998 - Nov 1998. 2001 Crisis is a dummy equal to 1 for Dec 2000 - Dec 2001. Sample period indicated in the column title. $R^{2}$ is within $R^{2}$. Errors are clustered at the bank and month levels. ${ }^{*} \mathrm{p}<0.10,{ }^{* *} \mathrm{p}<0.05,{ }^{* * *} \mathrm{p}$ $<0.01$ 
Table B9: Earthquake and Deposits - Robustness

\begin{tabular}{|c|c|c|c|c|c|c|}
\hline & \multicolumn{2}{|c|}{ Deposit Liabilities } & \multicolumn{4}{|c|}{ Non-Deposit Liabilities } \\
\hline & $\begin{array}{c}(1) \\
\text { Change }\end{array}$ & $\begin{array}{c}(2) \\
\text { Change }\end{array}$ & $\begin{array}{c}(3) \\
\text { Level }\end{array}$ & $\begin{array}{c}(4) \\
\text { Level }\end{array}$ & $\begin{array}{c}(5) \\
\text { Change }\end{array}$ & $\begin{array}{c}(6) \\
\text { Change }\end{array}$ \\
\hline Gov Bond Holdings $s_{i-1} \times$ Earthquake $_{t}$ & $\begin{array}{l}0.0519^{*} \\
(0.0276)\end{array}$ & $\begin{array}{c}0.0205 \\
(0.0258)\end{array}$ & $\begin{array}{l}-0.0770^{*} \\
(0.0440)\end{array}$ & $\begin{array}{l}-0.0608 \\
(0.0411)\end{array}$ & $\begin{array}{l}-0.0306^{*} \\
(0.0158)\end{array}$ & $\begin{array}{l}-0.0196^{*} \\
(0.0105)\end{array}$ \\
\hline Gov Bond Holdings $\mathrm{s}_{i t-1}$ & $-0.112^{*}$ & -0.0685 & 0.0587 & 0.0395 & $0.0470^{* *}$ & $0.0304^{* * *}$ \\
\hline Gov Bond Holdings $s_{i t-1} \times$ Russia $_{t}$ & & $(0.0396)$ & & $(0.0408)$ & & $\begin{array}{c}-0.0722^{* * *} \\
(0.0267)\end{array}$ \\
\hline Gov Bond Holdings $s_{i t-1} \times$ Asia $_{t}$ & & -0.00580 & & 0.0678 & & 0.0108 \\
\hline Gov Bond Holdings $_{i t-1} \times 2001$ Crisis $_{t}$ & & $\begin{array}{l}-0.125^{* *} \\
(0.0575)\end{array}$ & & $\begin{array}{c}0.0506 \\
(0.0836)\end{array}$ & & $\begin{array}{l}0.0516 \\
(0.0384)\end{array}$ \\
\hline Observations & 5057 & 5057 & 5059 & 5059 & 5057 & 5057 \\
\hline$R^{2}$ & 0.100 & 0.104 & 0.268 & 0.269 & 0.0263 & 0.0306 \\
\hline Banks & 82 & 82 & 82 & 82 & 82 & 82 \\
\hline BankFE & Yes & Yes & Yes & Yes & Yes & Yes \\
\hline TimeFE & Yes & Yes & Yes & Yes & Yes & Yes \\
\hline Controls & Yes & Yes & Yes & Yes & Yes & Yes \\
\hline
\end{tabular}

Dependent variable is listed in the column titles, and computed as a ratio of total assets. Non-deposit liabilities (levels and changes) is winsorized at 1\%. Controls include changes in (or for columns 3-4, lagged values of) cash holdings relative to assets, private lending to assets, interbank balances to assets, and log assets, where cash is winsorized at 1\%. Earthquake is a dummy equal to 1 for Aug 1999 - Nov 1999. Asia is a dummy equal to 1 for Jul 1997- Oct 1997. Russia is a dummy equal to 1 for Sep 1998 - Nov 1998. 2001 Crisis is a dummy equal to 1 for Dec 2000 - Dec 2001. Controls include lagged values of interbank assets, cash holdings, log assets, and capital. All variables (except log assets) are normalized by assets. Cash and capital are winsorized at $1 \%$. Sample spans 1997-2002. $R^{2}$ is within $R^{2}$. Errors are clustered at the bank and month levels. ${ }^{*} \mathrm{p}<0.10,{ }^{* *} \mathrm{p}<0.05,{ }^{* * *} \mathrm{p}<0.01$ 